\title{
Genetic Types and Source of the Upper Paleozoic Tight Gas in the Hangjinqi Area, Northern Ordos Basin, China
}

\author{
Xiaoqi Wu, ${ }^{1}$ Chunhua Ni, ${ }^{1}$ Quanyou Liu, ${ }^{2,3}$ Guangxiang Liu, ${ }^{1}$ \\ Jianhui Zhu, ${ }^{1}$ and Yingbin Chen ${ }^{1}$ \\ ${ }^{1}$ Wuxi Research Institute of Petroleum Geology, Petroleum Exploration and Production Research Institute, SINOPEC, Wuxi, \\ Jiangsu 214126, China \\ ${ }^{2}$ State Key Laboratory of Shale Oil and Gas Enrichment Mechanisms and Effective Development, Beijing 100083, China \\ ${ }^{3}$ Petroleum Exploration and Production Research Institute, SINOPEC, Beijing 100083, China
}

Correspondence should be addressed to Quanyou Liu; qyouliu@sohu.com

Received 21 December 2016; Accepted 24 April 2017; Published 29 May 2017

Academic Editor: Xiaorong Luo

Copyright (c) 2017 Xiaoqi Wu et al. This is an open access article distributed under the Creative Commons Attribution License, which permits unrestricted use, distribution, and reproduction in any medium, provided the original work is properly cited.

\begin{abstract}
The molecular and stable isotopic compositions of the Upper Paleozoic tight gas in the Hangjinqi area in northern Ordos Basin were investigated to study the geochemical characteristics. The tight gas is mainly wet with the dryness coefficient $\left(\mathrm{C}_{1} / \mathrm{C}_{1-5}\right)$ of 0.853-0.951, and $\delta^{13} \mathrm{C}_{1}$ and $\delta^{2} \mathrm{H}-\mathrm{C}_{1}$ values are ranging from $-36.2 \%$ to $-32.0 \%$ and from $-199 \%$ to $-174 \%$, respectively, with generally positive carbon and hydrogen isotopic series. Identification of gas origin indicates that tight gas is mainly coal-type gas, and it has been affected by mixing of oil-type gas in the wells from the Shilijiahan and Gongkahan zones adjacent to the Wulanjilinmiao and Borjianghaizi faults. Gas-source correlation indicates that coal-type gas in the Shiguhao zone displays distalsource accumulation. It was mainly derived from the coal-measure source rocks in the Upper Carboniferous Taiyuan Formation $\left(\mathrm{C}_{3} \mathrm{t}\right)$ and Lower Permian Shanxi Formation $\left(\mathrm{P}_{1} \mathrm{~s}\right)$, probably with a minor contribution from $\mathrm{P}_{1} \mathrm{~s}$ coal measures from in situ Shiguhao zone. Natural gas in the Shilijiahan and Gongkahan zones mainly displays near-source accumulation. The coal-type gas component was derived from in situ $\mathrm{C}_{3} \mathrm{t}-\mathrm{P}_{1}$ s source rocks, whereas the oil-type gas component might be derived from the carbonate rocks in the Lower Ordovician Majiagou Formation $\left(\mathrm{O}_{1} \mathrm{~m}\right)$.
\end{abstract}

\section{Introduction}

Geochemical characteristics of natural gas are fundamental to the study on the origin, migration, accumulation, and alteration of natural gas and have played an important role in revealing the organic type, thermal evolution degree, and sedimentary environment of source rocks of natural gas $[1-8]$. The studies on the origin and source of natural gas especially unconventional gas in China have achieved significant progress in recent years [9-15]. Tight gas has made the most contribution to the rapid increase of unconventional gas output and reserves in China, and the reserves and annual production of tight gas in China at the end of 2010 accounted for $39.2 \%$ and $24.6 \%$ of the total natural gas, respectively [16]. Therefore, tight gas has been considered in priority in the exploration and exploitation of unconventional gas in
China [16]. There were 16 tight gas fields in the 48 large gas fields discovered in China by the end of 2011, suggesting the crucial importance of this type of reservoirs in China. The gas production of these 16 large tight gas fields in 2011 was 26.799 $\times 10^{9} \mathrm{~m}^{3}$, accounting for $26.1 \%$ of the total gas production in China [17].

The Ordos Basin, a petroliferous basin located in central China, is the most productive basin with the highest annual gas output in China [18]. The exploration targets for natural gas in the Ordos Basin mainly consist of the Upper Paleozoic Carboniferous-Permian tight sandstone and the Lower Paleozoic Ordovician carbonate reservoirs. Several giant Upper Paleozoic tight gas fields with proven reserves over $100 \times 10^{9} \mathrm{~m}^{3}$ have been discovered in the Carboniferous-Permian tight sandstone, for example, Sulige, 
Yulin, Daniudi, Wushenqi, and Zizhou. The Upper Paleozoic natural gas is commonly considered as coal-type gas from the Carboniferous-Permian coal-measure source rocks [1926]. However, the Lower Paleozoic natural gas was generally believed to be mixed by both coal-type gas from the Upper Paleozoic coal measures and oil-type gas from the marine source rocks [27-29].

The Hangjinqi area is located in northern Ordos Basin, and the gas exploration has achieved continuous breakthroughs in recent years. Natural gas is mainly enriched in the Upper Paleozoic tight sandstone reservoirs, with few discoveries in the Mesoproterozoic strata such as wells J3 and $\mathrm{J13}$ [30]. The geological reserves of tight gas in the Hangjinqi area are higher than $700 \times 10^{9} \mathrm{~m}^{3}$, and the Upper Paleozoic tight gas reservoirs are characterized by the lithological traps, large gas-bearing area, and low abundance of reserves [31]. Previous studies have been conducted on the Mesozoic tectonic evolution [32], segmentation of the faults [33], geochemical characteristics of the source rocks $[34,35]$, and the origin of natural gas [36]. Moreover, Hao et al. [31] demonstrated the forming conditions of the gas reservoirs, and Wang et al. [37] proposed the accumulating mechanism of natural gas based on the analysis of trap conditions. However, there is no consensus on the source and accumulating pattern of natural gas. Although the Upper Paleozoic tight gas in the Hangjinqi area was commonly believed to be sourced from the Carboniferous-Permian coal measures, it is still controversial whether the gas was derived from the source rocks in in situ Hangjinqi area $[34,35]$ or the Wushenqi area in central Ordos Basin [37]. Wang et al. [37] proposed that advantageous sandbody, unconformity, faults, and fissures constituted favorable migration pathways for the northward migration natural gas. Nevertheless, Xue et al. [34] considered that the strata in the Ordos Basin were gentle with a low dip angle, and the conditions for large-scale lateral migration were undeveloped in consideration of the Upper Paleozoic tight sandstone reservoirs. Hao et al. [31] and Chen et al. [36] demonstrated that the Upper Paleozoic natural gas to the south and north of the Sanyanjing-WulanjilinmiaoBorjianghaizi fault zones displayed near-source and distalsource accumulation, respectively. However, Xue et al. [34] proposed that the Upper Paleozoic natural gas in the Hangjinqi area displayed near-source accumulation and was derived from in situ Upper Paleozoic coal-measure source rocks.

The above controversy is mainly derived from the different understandings on the geological conditions of tight gas in the Hangjinqi area, and geochemical characteristics of tight gas in the area have been weakly studied with a few confusions. Chen et al. [36] demonstrated that natural gas in the Shiguhao zone in northern Hangjinqi area was partially derived from source rocks in the Shilijiahan area to the south of the Borjianghaizi fault, and the gas had been affected by compositional geochromatographic effect and carbon isotopic fractionation. However, natural gas in the Shiguhao zone displayed obviously higher $\delta^{13} \mathrm{C}_{1}$ values and $C_{1} / C_{1-5}$ ratios than those in the Shilijiahan zone [36], suggesting higher maturity rather than the migration effect.
The generation and alteration processes of natural gas can be revealed by the study of genetic and postgenetic molecular and isotopic fractionations based on the gas geochemical characteristics $[2,38]$. Therefore, the authors intend to document the geochemical characteristics of the Upper Paleozoic tight gas based on the analyses of molecular and stable isotopic compositions in this study. We further demonstrate the origin, source, and possible postgenetic processes of tight gas in comparison with the Lower Paleozoic gas in the Jingbian gas field. This would provide valuable information for the accumulation and resource evaluation of natural gas in the Ordos Basin.

\section{Geological Setting}

The Ordos Basin is a multicycle cratonic basin with stable subsidence and located at the western margin of the North China Block covering an area of $37 \times 10^{4} \mathrm{~km}^{2}$ [44]. Based on the basement property and the present tectonic morphology and characteristics, the Ordos Basin can be divided into 6 tectonic units (Figure 1), that is, Yimeng Uplift, Weibei Uplift, Jinxi Fault-fold Belt, Yishan Slope, Tianhuan Depression, and West Margin Thrust Belt [24, 45].

The Hangjinqi area is located tectonically in the Yimeng Uplift and northern Yishan Slope covering an area of $9825 \mathrm{~km}^{2}$. It can be subdivided into 5 secondary structural units according to the fluctuation characteristics and structural configuration of the top surface of the basement, that is, Wulangeer uplift, Gongkahan uplift, Hangjinqi fault terrace, northern Yishan Slope, and the northeastern corner of the Tianhuan Depression (Figure 1). Three main faults are distributed in the Hangjinqi area from west to east, in which the Sanyanjing and Wulanjilinmiao faults are southdipping normal faults, whereas the Borjianghaizi fault is north-dipping thrust fault (Figure 1). Seven gas zones, that is, Haoraozhao, Shiguhao, Shilijiahan, Azhen, Gongkahan, Wulanjilinmiao, and Xinzhao, are classified according to the fault distribution (Figure 1). The Hangjinqi area was topographically a long-term inherited paleohigh in northern Ordos Basin and was considered as the favorable oriented region for oil and gas migration [46]. Gas reservoirs are found mainly in the Shiguhao and Shilijiahan zones.

The Upper Paleozoic strata in the Hangjinqi area unconformably overlie the Lower Ordovician Majiagou Formation $\left(\mathrm{O}_{1} \mathrm{~m}\right)$ or Meso-Neoproterozoic strata $\left(\mathrm{Pt}_{2}-\mathrm{Pt}_{3}\right)$, and they consist upward of the Upper Carboniferous Taiyuan Fm. $\left(\mathrm{C}_{3} \mathrm{t}\right)$, Lower Permian Shanxi Fm. $\left(\mathrm{P}_{1} \mathrm{~s}\right)$, and Lower Shihezi Fm. $\left(\mathrm{P}_{1} \mathrm{x}\right)$, as well as Upper Permian Upper Shihezi Fm. $\left(\mathrm{P}_{2} \mathrm{sh}\right)$ and Shiqianfeng Fm. $\left(\mathrm{P}_{2} \mathrm{~s}\right)$ (Figure 2). Natural gas is mainly reservoired in the $\mathrm{P}_{1} \mathrm{x}$ tight sandstone with only a few discoveries in the $\mathrm{P}_{1} \mathrm{~s}$ and $\mathrm{C}_{3} \mathrm{t}$ sandstones, and these sandstone reservoirs are generally characterized by low porosity and permeability [37]. The $\mathrm{P}_{2}$ sh and $\mathrm{P}_{2}$ s strata are mainly composed of thick-layer lacustrine mudstone interbedded with sandstone, and the mudstone is widely and stably distributed with the thickness of $130 \mathrm{~m}-160 \mathrm{~m}$, constituting the regional caprock for the underlying $\mathrm{P}_{1} \mathrm{x}$ and $\mathrm{P}_{1} \mathrm{~s}$ tight gas reservoirs [31]. Moreover, natural gas has also 


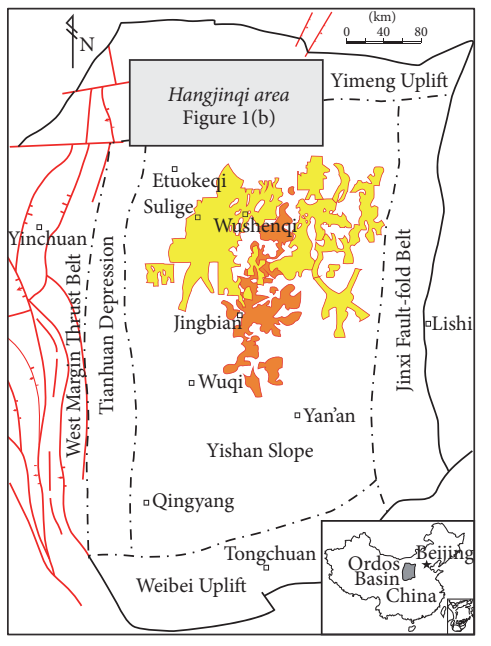

(a)
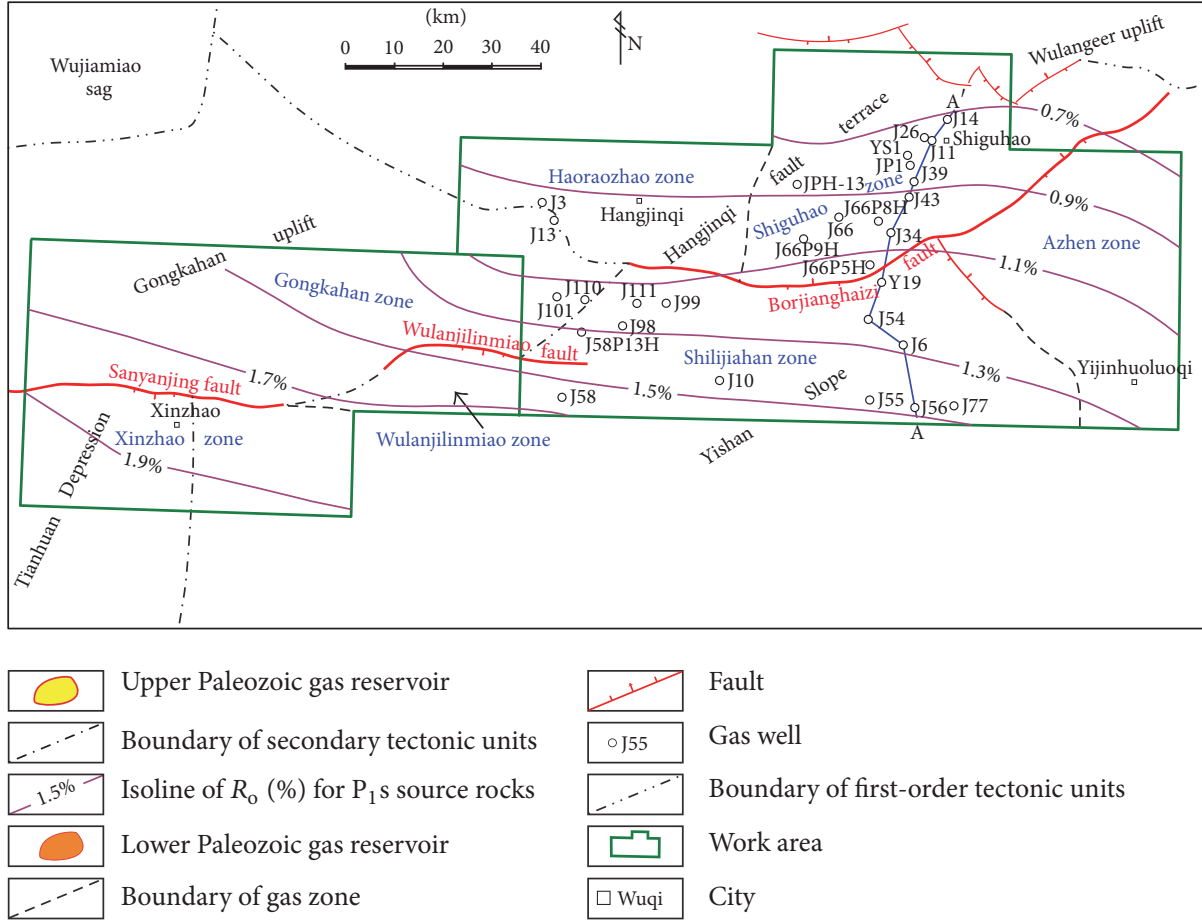

Upper Paleozoic gas reservoir

Boundary of secondary tectonic units

Isoline of $R_{\mathrm{o}}(\%)$ for $\mathrm{P}_{1}$ s source rocks

Lower Paleozoic gas reservoir

Boundary of gas zone

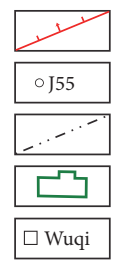

Fault

Gas well

Boundary of first-order tectonic units

Work area

City

FIGURE 1: (a) Location map of the Hangjinqi area and the distribution of tectonic units in the Ordos Basin; (b) distribution map of the tectonic units, gas zones, and gas wells in the Hangjinqi area. The isolines of $R_{\mathrm{o}}(\%)$ are modified after Ji et al. [35].

been discovered in the Mesoproterozoic strata $\left(\mathrm{Pt}_{2}\right)$ in only a few wells with low gas production [30].

The $\mathrm{C}_{3} \mathrm{t}$ and $\mathrm{P}_{1} \mathrm{~s}$ coal measures are the main Upper Paleozoic source rocks and composed of coal seam and dark mudstone, with the average TOC contents of $56.92 \%$ and $3.01 \%$, respectively [31]. The thickness of the $\mathrm{C}_{3} \mathrm{t}-\mathrm{P}_{1} \mathrm{~s}$ source rocks decreases gradually from southeast to northwest, and the $\mathrm{P}_{1} \mathrm{~s}$ source rocks are distributed all over the Hangjinqi area; however, the $\mathrm{C}_{3} \mathrm{t}$ source rocks display the largest thickness of $20 \mathrm{~m}$ to the south of the Borjianghaizi fault and are generally undeveloped to the north of the fault [47]. The $\mathrm{C}_{3} \mathrm{t}-\mathrm{P}_{1} \mathrm{~s}$ coal-measure source rocks in the Hanginqi area are mainly gas-prone with kerogen type III, and the thermal maturity increases from north to south and is mainly in the range of $0.8 \%-1.7 \%$, and the vitrinite reflectance $\left(R_{\mathrm{o}}\right)$ values are generally higher and lower than $1.1 \%$ to the south and north of the Borjianghaizi fault (Figure 1), respectively $[34,35]$. The gas generation intensity of the $\mathrm{C}_{3} \mathrm{t}-\mathrm{P}_{1}$ s coalmeasure source rocks is mainly $(15-30) \times 10^{8} \mathrm{~m}^{3} / \mathrm{km}^{2}$ to the south of the Sanyanjing-Wulanjilinmiao-Borjianghaizi faults and is $0-10 \times 10^{8} \mathrm{~m}^{3} / \mathrm{km}^{2}$ in the Shiguhao zone to the north of the Borjianghaizi fault [31]. The gas generation intensity is $(5-10) \times 10^{8} \mathrm{~m}^{3} / \mathrm{km}^{2}$ on the north side near the SanyanjingWulanjilinmiao faults; however, the Upper Paleozoic strata far away from and to the north of the fault zones have little gas generation capacity as a result of the undevelopment of the source rocks [31].

\section{Analytical Methods}

16 gas samples from the Upper Paleozoic $\left(\mathrm{P}_{1} \mathrm{~s}-\mathrm{P}_{1} \mathrm{x}\right)$ tight sandstone reservoirs in the Hangjinqi area in northern Ordos Basin were collected from the wellheads after first flushing the lines for 15-20 min to remove air contamination, and 1 gas sample from the Mesoproterozoic stratum was also collected for comparative analysis. The gas samples were collected using $5 \mathrm{~cm}$ radius stainless steel cylinders with double valves and analyzed at Wuxi Research Institute of Petroleum Geology, Petroleum Exploration and Production Research Institute (PEPRIS) of SINOPEC.

The chemical composition of gas samples was determined using an Agilent 7890A gas chromatograph (GC) equipped with a flame ionization detector and a thermal conductivity detector. Individual alkane gas components were separated using a capillary column (PLOT $\mathrm{Al}_{2} \mathrm{O}_{3} 50 \mathrm{~m} \times 0.53 \mathrm{~mm}$ ). The GC oven temperature was initially set at $40^{\circ} \mathrm{C}$ for $5 \mathrm{~min}$, heating at a rate of $10^{\circ} \mathrm{C} / \mathrm{min}$ to a final temperature of $180^{\circ} \mathrm{C}$, which was held for $20 \mathrm{~min}$.

Stable carbon isotopic composition of the natural gas was measured on a Finnigan MAT-253 mass spectrometer. The alkane gas components were initially separated using a fused silica capillary column (PLOT Q $30 \mathrm{~m} \times 0.32 \mathrm{~mm}$ ) with helium carrier gas. The oven temperature was ramped from 40 to $180^{\circ} \mathrm{C}$ at a heating rate of $10^{\circ} \mathrm{C} / \mathrm{min}$, and the final temperature was held for $10 \mathrm{~min}$. Each gas sample was measured in triplicate. Stable carbon isotopic values are 


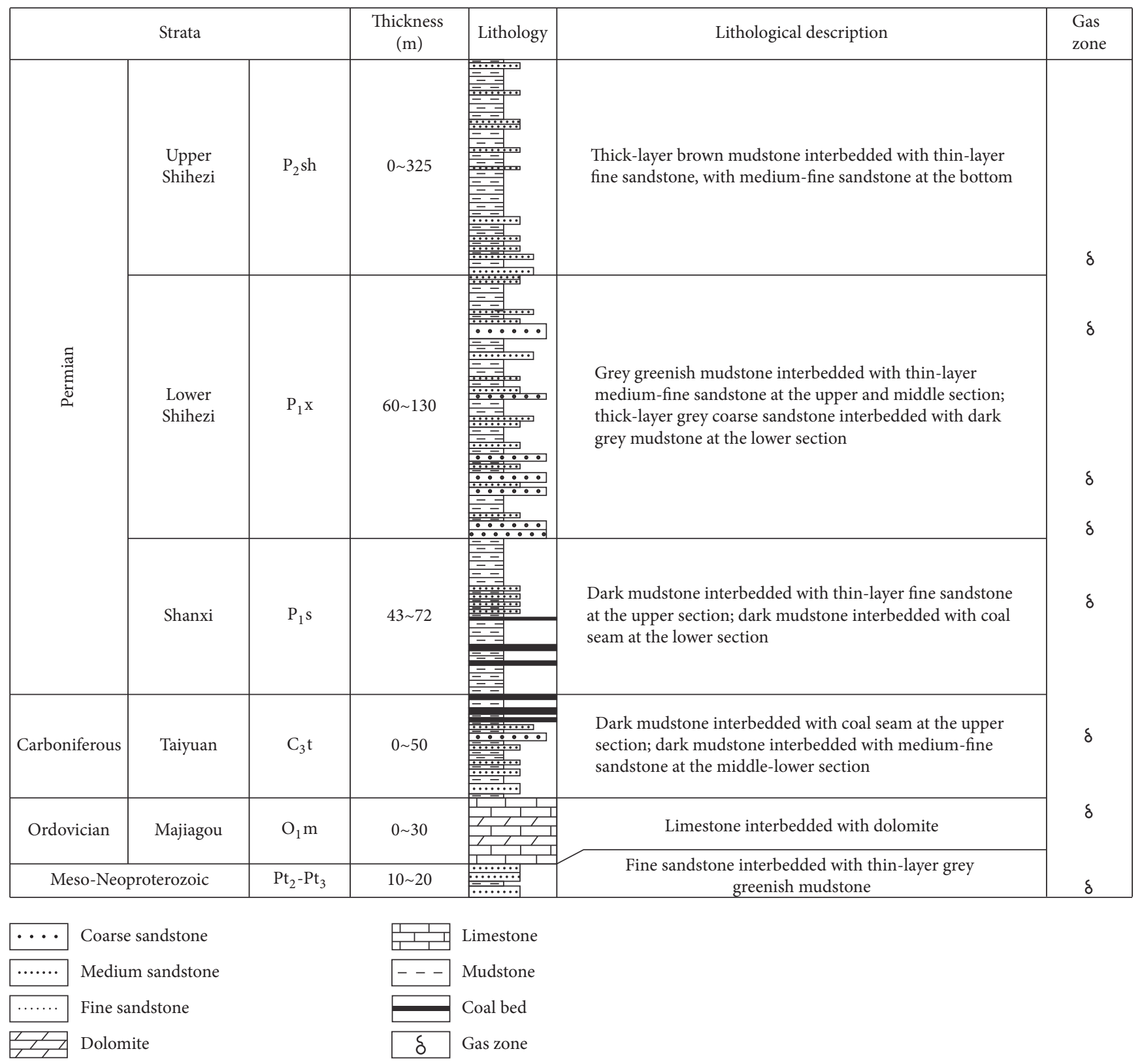

Figure 2: Stratigraphic column of the Hangjinqi area in the Ordos Basin.

reported in the $\delta$ notation in permil (\%o) relative to VPDB, and the measurement precision is estimated to be $\pm 0.5 \%$ for $\delta^{13} \mathrm{C}$.

Stable hydrogen isotopic composition of alkane gases was measured on a Thermo Scientific Delta V Advantage mass spectrometer (GC/TC/IRMS). The alkane gas components were separated on a HP-PLOT Q column $(30 \mathrm{~m} \times 0.32 \mathrm{~mm}$ $\times 20 \mu \mathrm{m}$ ) with helium carrier gas at $1.5 \mathrm{ml} / \mathrm{min}$. The $\mathrm{GC}$ oven was initially held at $30^{\circ} \mathrm{C}$ for $5 \mathrm{~min}$ and then programmed to $80^{\circ} \mathrm{C}$ at $8^{\circ} \mathrm{C} / \mathrm{min}$ and then heated to $260^{\circ} \mathrm{C}$ at $4^{\circ} \mathrm{C} / \mathrm{min}$ where it was held for $10 \mathrm{~min}$. Each gas sample was measured in triplicate and the results were averaged. The measurement precision is estimated to be $\pm 3 \%$ o for $\delta^{2} \mathrm{H}$ with respect to VSMOW.

\section{Results}

The molecular and stable isotopic compositions of the Upper Paleozoic tight gas from the Hangjinqi area are listed in Table 1.

4.1. Chemical Composition of Natural Gas. The $\mathrm{P}_{1} \mathrm{~s}-\mathrm{P}_{1} \mathrm{x}$ tight gas in the Hangjinqi area in northern Ordos Basin is dominated by methane with $\mathrm{CH}_{4}$ and $\mathrm{C}_{2-5}$ contents in the ranges of $83.48 \%-93.72 \%$ and $4.81 \%-14.49 \%$, respectively. The gas is generally wet with dryness coefficient $\left(\mathrm{C}_{1} / \mathrm{C}_{1-5}\right)$ in the range of 0.853-0.951, which is mainly lower than 0.95 (Table 1 ), and $\mathrm{CH}_{4}$ content is positively correlated with the $\mathrm{C}_{1} / \mathrm{C}_{1-5}$ ratio (Figure 3(a)). The $\mathrm{Pt}_{2}$ gas sample from Well J101 displays $\mathrm{CH}_{4}$ 


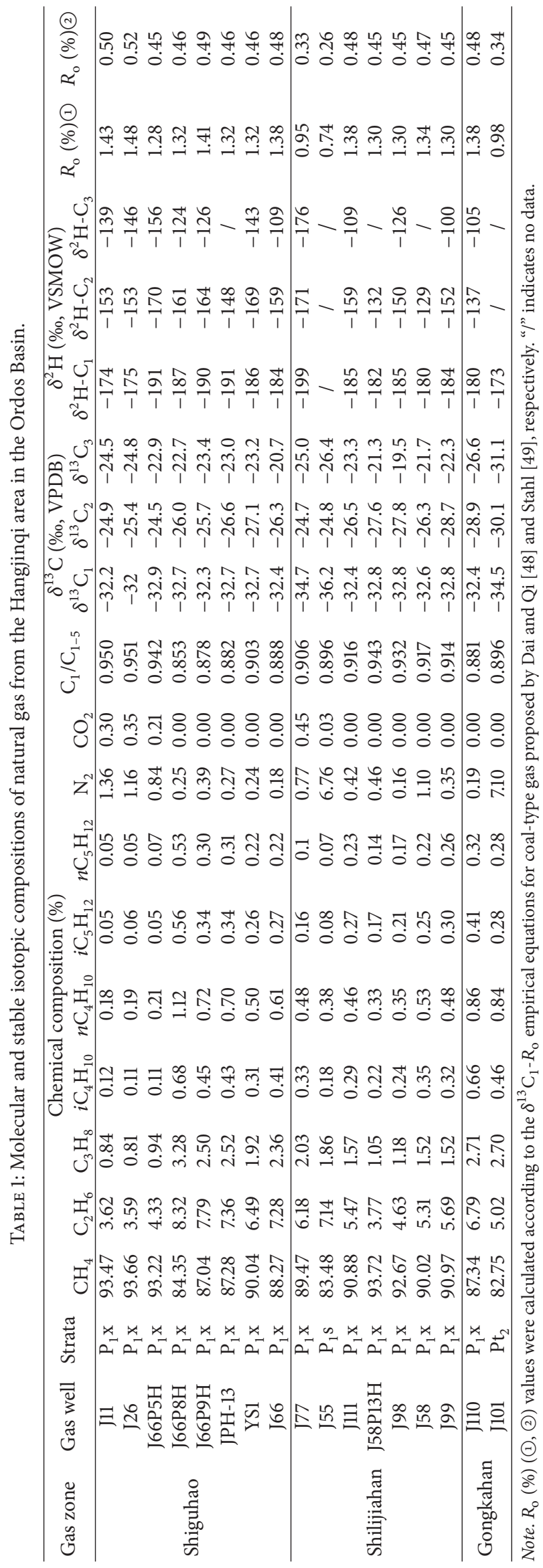




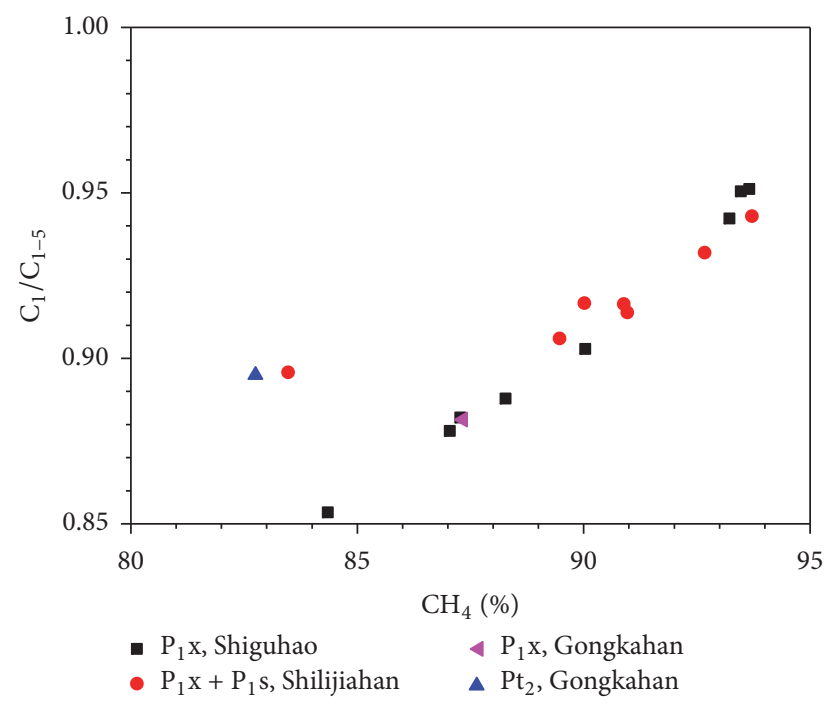

(a)

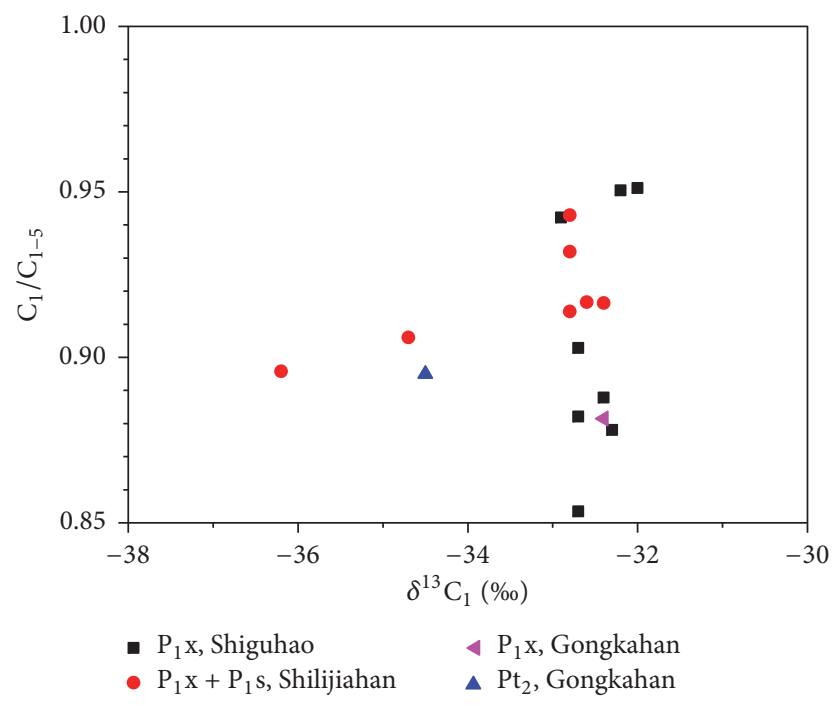

(b)

Figure 3: Correlation diagrams of dryness coefficient $\left(\mathrm{C}_{1} / \mathrm{C}_{1-5}\right)$ versus $\mathrm{CH}_{4} \%$ (a) and $\mathrm{C}_{1} / \mathrm{C}_{1-5}$ ratio versus $\delta^{13} \mathrm{C}_{1}$ value (b) of tight gas from the Hangjinqi area in the Ordos Basin.

content of $82.75 \%$, which is lower than the $\mathrm{P}_{1} \mathrm{~s}-\mathrm{P}_{1} \mathrm{x}$ tight gas, and it is also wet gas with $\mathrm{C}_{1} / \mathrm{C}_{1-5}$ ratio of 0.896 (Table 1 , Figure 3(a)).

The $\mathrm{P}_{1} \mathrm{~s}-\mathrm{P}_{1} \mathrm{x}$ tight gas in the Hangjinqi area contains few amount of $\mathrm{CO}_{2}$ with the content of $0 \%-0.45 \%$, and the nonhydrocarbon component is mainly $\mathrm{N}_{2}$ with the content mainly in the range of $0.16 \%-1.36 \%$ (Table 1). Only one sample (J55) has $\mathrm{N}_{2}$ content of $6.76 \%$, which is similar to the $\mathrm{Pt}_{2}$ gas sample from Well J101 (Table 1). This might be caused by the application of the technology of nitrogen gaslift recovery, which would not affect the carbon and hydrogen isotopic compositions of alkane gas. Therefore, the carbon and hydrogen isotopic compositions of the gas samples could be used to identify the gas origin.

4.2. Carbon Isotopic Composition. $\delta^{13} \mathrm{C}_{1}$ value of the alkanes in the $\mathrm{P}_{1} \mathrm{~s}-\mathrm{P}_{1} \mathrm{x}$ tight gas in the Hangjinqi area is from $-36.2 \%$ to $-32.0 \%$, and it is uncorrelated with the dryness coefficient $\left(\mathrm{C}_{1} / \mathrm{C}_{1-5}\right)$ (Table 1, Figure 3(b)). The $\mathrm{P}_{1} \mathrm{~s}-\mathrm{P}_{1} \mathrm{x}$ alkane gas displays variable $\mathrm{C}_{1} / \mathrm{C}_{1-5}$ ratio and nearly constant $\delta^{13} \mathrm{C}_{1}$ value (from $-32.9 \%$ o to $-32.0 \%$ ) except two gas samples (J55, J77) (Table 1, Figure 3(b)). $\delta^{13} \mathrm{C}_{1}$ value of the $\mathrm{Pt}_{2}$ gas sample from Well J101 is $-34.5 \%$, which is slightly lower than the main value of the $\mathrm{P}_{1} \mathrm{~s}-\mathrm{P}_{1} \mathrm{x}$ gas (Table 1, Figure $3(\mathrm{~b})$ ).

$\delta^{13} \mathrm{C}_{2}$ and $\delta^{13} \mathrm{C}_{3}$ values of the $\mathrm{P}_{1} \mathrm{~s}-\mathrm{P}_{1} \mathrm{x}$ alkane gas are from $-28.9 \%$ o to $-24.5 \%$ and from $-26.6 \%$ o to $-19.5 \%$, respectively, whereas those of the $\mathrm{Pt}_{2}$ gas sample are $-30.0 \%$ o and $-31.1 \%$, respectively (Table 1 , Figure 4 ). The $\mathrm{P}_{1} \mathrm{~s}-\mathrm{P}_{1} \mathrm{x}$ alkane gas generally displays positive carbon isotopic series $\left(\delta^{13} \mathrm{C}_{1}<\delta^{13} \mathrm{C}_{2}<\delta^{13} \mathrm{C}_{3}\right)$, with only two gas samples (J55, J77) displaying partial reversal between $\mathrm{C}_{2} \mathrm{H}_{6}$ and $\mathrm{C}_{3} \mathrm{H}_{8}$ carbon isotopes $\left(\delta^{13} \mathrm{C}_{2}>\delta^{13} \mathrm{C}_{3}\right)$, which are consistent with the $\mathrm{Pt}_{2}$ gas sample from Well J101 (Figure 4).

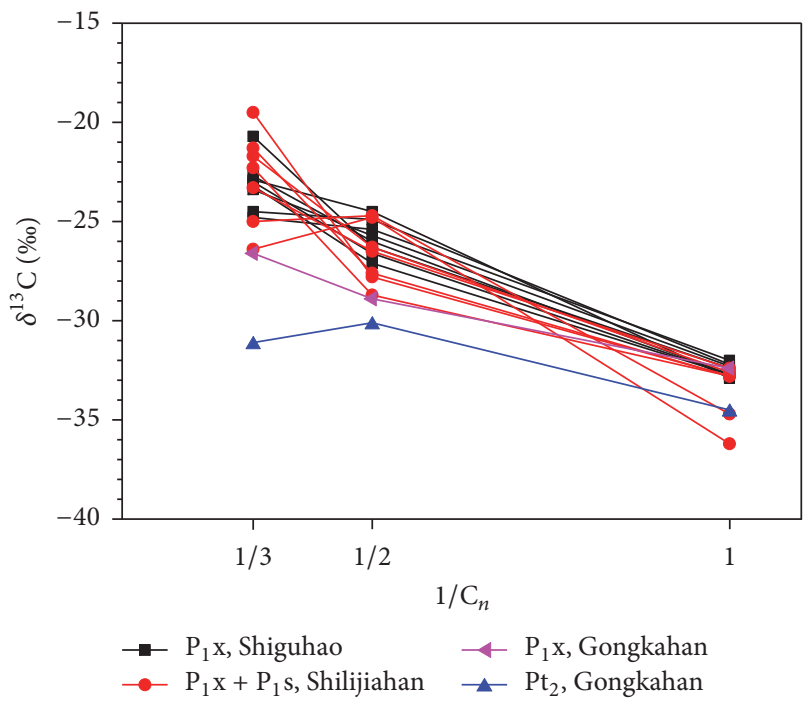

FIGURE 4: Carbon isotopic series of alkane gas in the Hangjinqi area in the Ordos Basin.

4.3. Hydrogen Isotopic Composition. $\delta^{2} \mathrm{H}-\mathrm{C}_{1}$ value of the $\mathrm{P}_{1} \mathrm{~s}$ $\mathrm{P}_{1} \mathrm{x}$ alkane gas in the Hangjinqi area is from $-199 \%$ to $-174 \%$, whereas that of the $\mathrm{Pt}_{2}$ gas sample from Well J101 is $-173 \%$, and it is slightly higher than that of the $\mathrm{P}_{1} \mathrm{~s}-\mathrm{P}_{1} \mathrm{x}$ gas (Table 1, Figure 5). $\delta^{2} \mathrm{H}-\mathrm{C}_{2}$ and $\delta^{2} \mathrm{H}-\mathrm{C}_{3}$ values of the $\mathrm{P}_{1} \mathrm{~s}-\mathrm{P}_{1} \mathrm{x}$ alkane gas are from $-171 \%$ to $-129 \%$ and from $-176 \%$ to $-100 \%$, respectively. The alkane gas generally displays positive hydrogen isotopic series $\left(\delta^{2} \mathrm{H}-\mathrm{C}_{1}<\delta^{2} \mathrm{H}-\mathrm{C}_{2}<\delta^{2} \mathrm{H}-\mathrm{C}_{3}\right)$ with only one gas sample (J77) being partially reversed between $\mathrm{C}_{2} \mathrm{H}_{6}$ and $\mathrm{C}_{3} \mathrm{H}_{8}$ hydrogen isotopes $\left(\delta^{2} \mathrm{H}-\mathrm{C}_{2}>\delta^{2} \mathrm{H}\right.$ $\mathrm{C}_{3}$ ) (Table 1, Figure 5). 


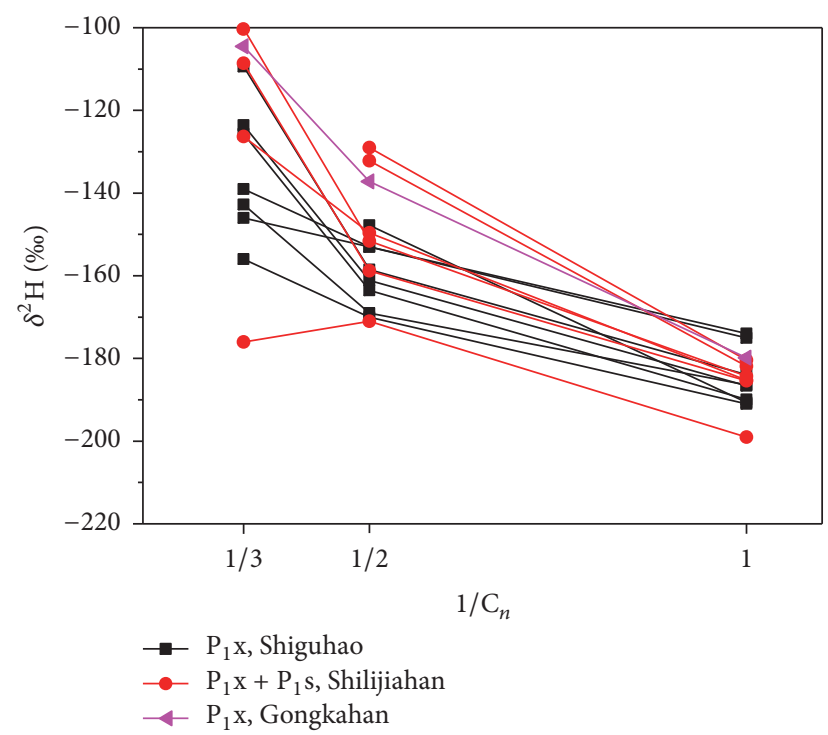

FIGURE 5: Hydrogen isotopic series of alkane gas from the Hangjinqi area in the Ordos Basin.

\section{Discussion}

5.1. Origin of Tight Gas. The Upper Paleozoic $\left(\mathrm{P}_{1} \mathrm{~s}-\mathrm{P}_{1} \mathrm{x}\right)$ alkane gas in the Hangjinqi area in northern Ordos Basin mainly displays positive carbon and hydrogen isotopic series (Figures 4 and 5) with $\delta^{13} \mathrm{C}_{1}$ value higher than $-30 \%$ (Figure 3(b)), suggesting the typically biogenic gas rather than the abiogenic one [50]. The biogenic gas can be divided into bacterial gas and thermogenic gas, in which the bacterial gas is dominated by $\mathrm{CH}_{4}$ and extremely dry with $\mathrm{C}_{1} / \mathrm{C}_{1-5}$ ratio higher than 0.99 and $\delta^{13} \mathrm{C}_{1}$ value lower than $-55 \%$, whereas thermogenic gas generally displays $\delta^{13} \mathrm{C}_{1}$ value higher than $-50 \% 0[4,50]$. The $\mathrm{P}_{1} \mathrm{~s}-\mathrm{P}_{1} \mathrm{x}$ and $\mathrm{Pt}_{2}$ gases in the Hangjinqi area display $\delta^{13} \mathrm{C}_{1}$ value and dryness coefficient ranging from $-36.2 \%$ to $-32.0 \%$ and from 0.853 to 0.951 , respectively (Figure 3(b)). They are significantly different from the bacterial gas, and they follow the maturity trend rather than the biodegradation trend in correlation diagram between $\mathrm{C}_{2} / \mathrm{C}_{3}$ and $\mathrm{C}_{2} / i \mathrm{C}_{4}$ (Figure 6 ).

The $\mathrm{P}_{1} \mathrm{~s}-\mathrm{P}_{1} \mathrm{x}$ and $\mathrm{Pt}_{2}$ gases in the Hanginqi area display typical characteristics of thermogenic gas in the modified Bernard diagram (Figure 7). Thermogenic gas can be generally divided into coal-type gas from humic organic matter and oil-type gas from sapropelic organic matter $[3,50]$. The Upper Paleozoic tight gas in the Hangjinqi area follows the trend of natural gas from type III kerogen, suggesting the origin of coal-type gas (Figure 7). However, the $\mathrm{O}_{1} \mathrm{~m}$ gas in the Jingbian gas field lies in the mixing or transitional zone between gases from types II and III kerogens, which may indicate the trend of mixing between oil-type and coal-type gases (Figure 7). The $\mathrm{P}_{1} \mathrm{~s}-\mathrm{P}_{1} \mathrm{x}$ tight gas in the Hangjinqi area mainly displays a wide range of $\mathrm{C}_{1} / \mathrm{C}_{2+3}$ ratio $(7.27-21.30)$ with nearly constant $\delta^{13} \mathrm{C}_{1}$ value (from $-32.9 \%$ to $-32.0 \%$ ), indicating certain migration trend (Figure 7).

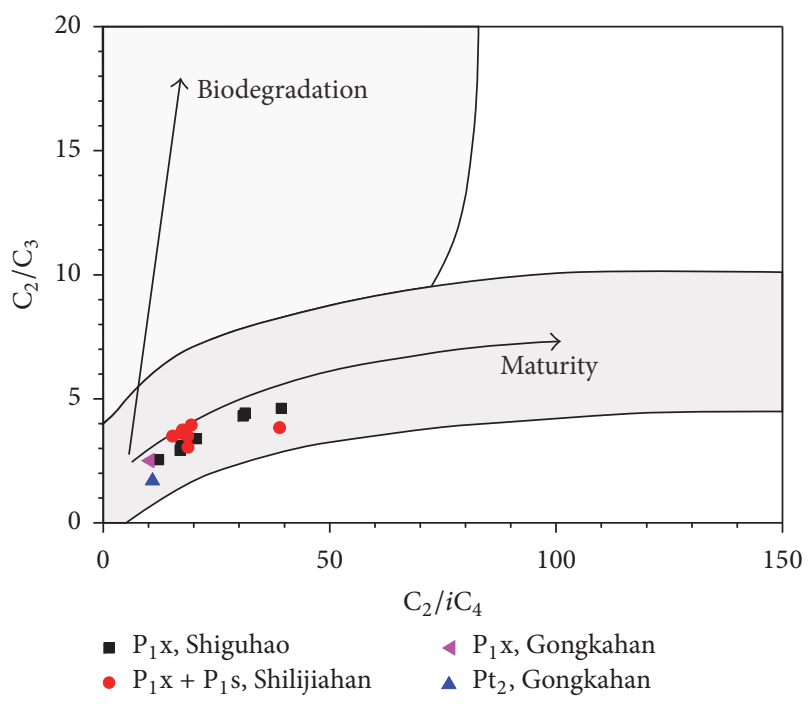

Figure 6: Correlation diagram between $\mathrm{C}_{2} / \mathrm{C}_{3}$ and $\mathrm{C}_{2} / i \mathrm{C}_{4}$ values of tight gas from the Hangjinqi area (modified after Prinzhofer and Battani [39]).

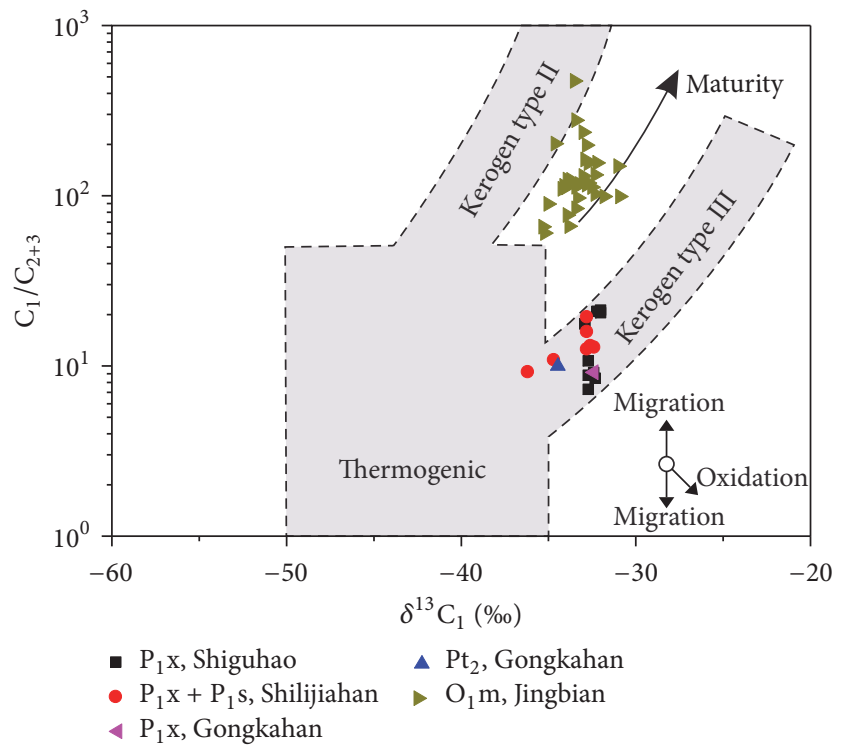

FIGURE 7: Modified Bernard diagram of tight gas from the Hangjinqi area (modified after Bernard et al. [40]). Data of the $\mathrm{O}_{1} \mathrm{~m}$ gas in the Jingbian gas fields are from Dai [18].

Since coal-type gas sourced from humic organic matter has relatively higher $\delta^{13} \mathrm{C}_{2}$ value than oil-type gas from sapropelic organic matter with similar $\delta^{13} \mathrm{C}_{1}$ value, they follow different evolution trends in correlation diagram between $\delta^{13} \mathrm{C}_{1}$ and $\delta^{13} \mathrm{C}_{2}$ values [3]. The $\mathrm{P}_{1} \mathrm{~s}-\mathrm{P}_{1} \mathrm{x}$ gas in the Hangjinqi area generally follows the trends of gases derived from type III kerogen in the Niger Delta [3] and Sacramento Bain [41], indicating the genetic type of coal-type gas (Figure $8(\mathrm{a})$ ). Several $\mathrm{P}_{1} \mathrm{x}$ gas samples are distributed in the transitional zone between gases from types II and III kerogens, and they display the characteristics of gas mixed by oil-type and 


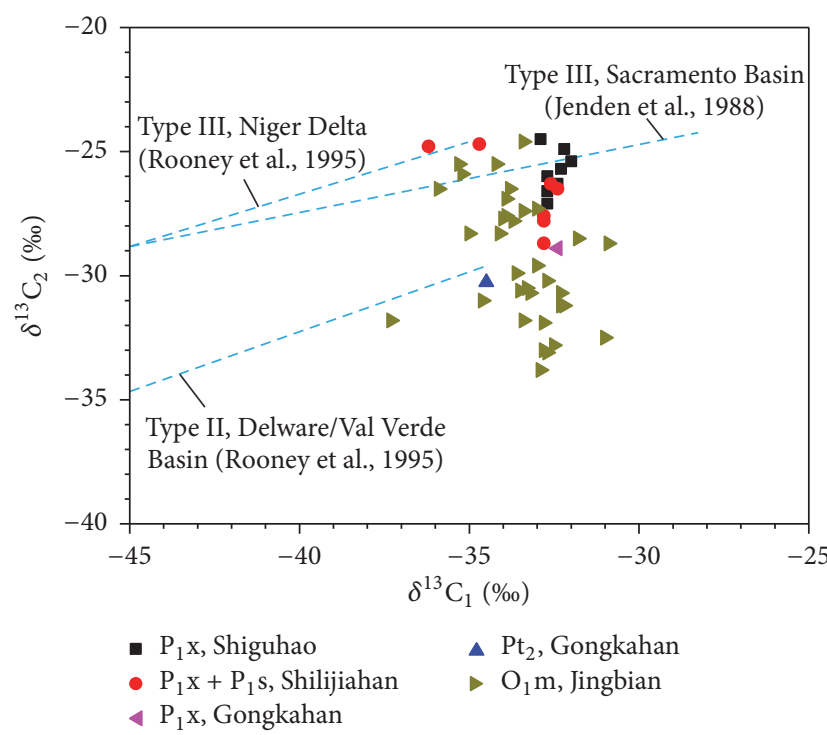

(a)

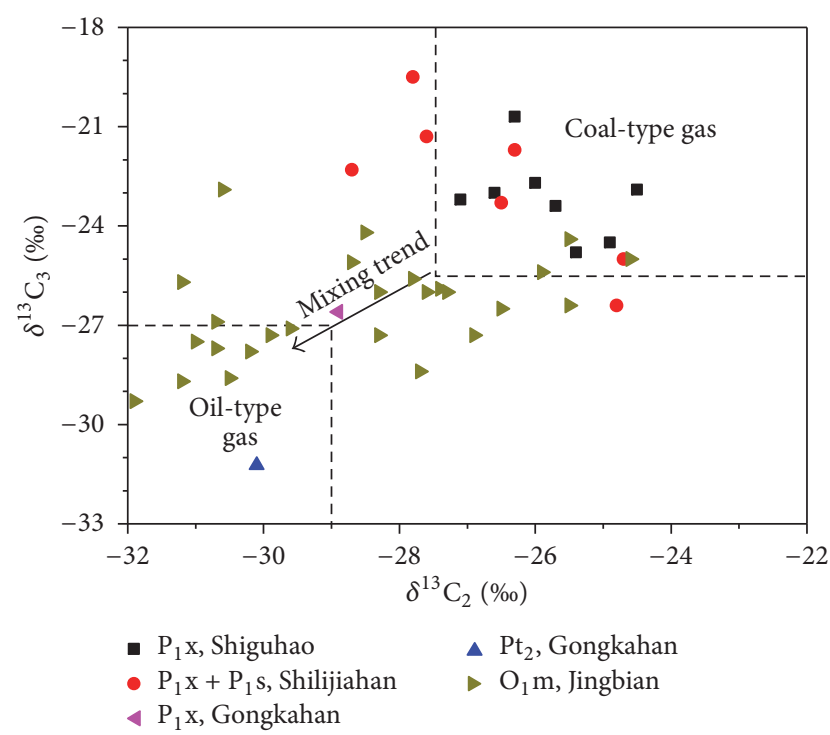

(b)

Figure 8: Cross-plots of $\delta^{13} \mathrm{C}_{2}$ versus $\delta^{13} \mathrm{C}_{1}(\mathrm{a})$ and $\delta^{13} \mathrm{C}_{3}$ versus $\delta^{13} \mathrm{C}_{2}$ (b) of tight gas from the Hangjinqi area. The trend lines for gases from kerogen type III of Niger Delta and kerogen type II of Delaware/Val Verde Basin are from Rooney et al. [3], and the trend lines for gas from kerogen type III of Sacramento Basin are from Jenden et al. [41]. $\delta^{13} \mathrm{C}_{2}$ and $\delta^{13} \mathrm{C}_{3}$ ranges for coal-type and oil-type gases in (b) are from Dai [42]. Data of the $\mathrm{O}_{1} \mathrm{~m}$ gas in the Jingbian gas fields are from Dai [18].

coal-type gases, which are similar to the $\mathrm{O}_{1} \mathrm{~m}$ gas in the Jingbian gas field (Figure 8(a)). The $\mathrm{Pt}_{2}$ gas sample from the Gongkahan zone follows the trend of gas derived from type II kerogen in the Delaware/Val Verde Basin [3], indicating the characteristics of oil-type gas (Figure 8(a)).

The carbon isotopes of ethane and propane generally inherited those of original organic matter and were effective indexes to identify the coal-type and oil-type gases [50]. Empirical observations indicated that $\delta^{13} \mathrm{C}_{2}$ and $\delta^{13} \mathrm{C}_{3}$ values of coal-type gas were generally higher than $-27.5 \%$ and $-25.5 \%$, respectively, whereas those of oil-type gas were lower than $-29.0 \%$ and $-27.0 \%$, respectively [42]. The $\mathrm{Pt}_{2}$ gas in the Gongkahan zone displays the characteristics of oiltype gas with low $\delta^{13} \mathrm{C}_{2}$ and $\delta^{13} \mathrm{C}_{3}$ values (Figure $8(\mathrm{~b})$ ). The $\mathrm{P}_{1} s-\mathrm{P}_{1} \mathrm{x}$ tight gas in the Hangjinqi area mainly displays the characteristics of coal-type gas, with several $\mathrm{P}_{1} \mathrm{x}$ gas samples from the Shilijiahan and Gongkahan zones displaying the trend of mixing with oil-type gas, and the proportion of oiltype gas seems generally lower than that in the $\mathrm{O}_{1} \mathrm{~m}$ gas in the Jingbian gas field (Figure 8(b)).

The hydrogen isotopic composition of natural gas is controlled by the type of organic matter, thermal maturity, and the environmental condition of the aqueous medium and has been effectively used to identify the gas origin $[1$, $50-52]$. The coal-type and oil-type gases display different distribution trends in correlation diagrams of both $\delta^{2} \mathrm{H}$ $\mathrm{C}_{1}$ versus $\delta^{13} \mathrm{C}_{1}$ and $\delta^{2} \mathrm{H}-\mathrm{C}_{1}$ versus $\delta^{13} \mathrm{C}_{2}$ [13]. The $\mathrm{P}_{1} \mathrm{~s}$ $\mathrm{P}_{1} \mathrm{x}$ gas in the Hangjinqi area displays the characteristics of gases from humic organic matter and generally follows the maturity trend in correlation diagram of $\delta^{2} \mathrm{H}-\mathrm{C}_{1}$ versus $\delta^{13} \mathrm{C}_{1}$ (Figure 9(a)), suggesting the genetic type of coal-type gas. The $\mathrm{O}_{1} \mathrm{~m}$ gas in the Jingbian gas field also displays the characteristics of gases from humic organic matter, which indicates that the gas is dominated by coal-type gas, and this is consistent with the conclusions of previous studies $[19,53]$. The $\mathrm{Pt}_{2}$ gas from the Gongkahan zone is plotted in the mixing or transitional zone, and it is adjacent to the zone of humic gases in correlation diagram of $\delta^{2} \mathrm{H}-\mathrm{C}_{1}$ versus $\delta^{13} \mathrm{C}_{1}$ (Figure 9(a)), which indicates that the $\mathrm{Pt}_{2}$ gas is dominated by coal-type gas and has been mixed by a small amount of oiltype gas.

In correlation diagram of $\delta^{2} \mathrm{H}-\mathrm{C}_{1}$ versus $\delta^{13} \mathrm{C}_{2}$ (Figure $9(\mathrm{~b})$ ), the $P_{1} x$ tight gas from the Shiguhao zone mainly displays the characteristics of coal-type gas, whereas the $\mathrm{P}_{1} \mathrm{~s}$ $\mathrm{P}_{1} \mathrm{x}$ gas in the Shilijiahan and Gongkahan zones generally follows the trend of mixing with oil-type gas, although it is adjacent to the range of coal-type gas. The $\mathrm{O}_{1} \mathrm{~m}$ gas in the Jingbian gas field also displays the mixing trend (Figure $9(\mathrm{~b})$ ), which is consistent with previous studies [28, 54]. However, it is generally closer to the range of oil-type gas than the $\mathrm{P}_{1} \mathrm{~s}$ $\mathrm{P}_{1} \mathrm{x}$ tight gas in the Shilijiahan and Gongkahan zones, and this indicates that the proportion of oil-type gas in the $\mathrm{O}_{1} \mathrm{~m}$ gas in the Jingbian gas field is probably higher (Figure 9(b)).

Therefore, the Upper Paleozoic tight gas in the Hangjinqi area in northern Ordos Basin is mainly composed of coaltype gas. $\delta^{13} \mathrm{C}_{2}$ and $\delta^{13} \mathrm{C}_{3}$ values indicate that tight gas in the Shilijiahan and Gongkahan zones has been generally mixed by oil-type gas, and it displays similar characteristics with the $\mathrm{Pt}_{2}$ gas from the Gongkahan zone and the $\mathrm{O}_{1} \mathrm{~m}$ gas in the Jingbian gas field. The proportion of oil-type gas in the Upper Paleozoic gas in the Shilijiahan and Gongkahan zones is slightly lower than that in the $\mathrm{O}_{1} \mathrm{~m}$ gas in the Jingbian gas field. 


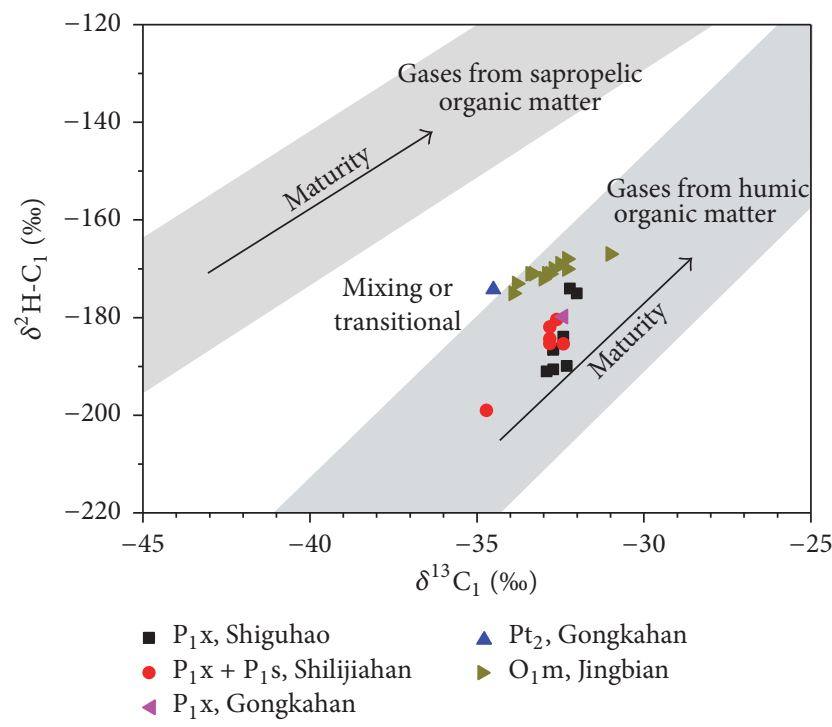

(a)

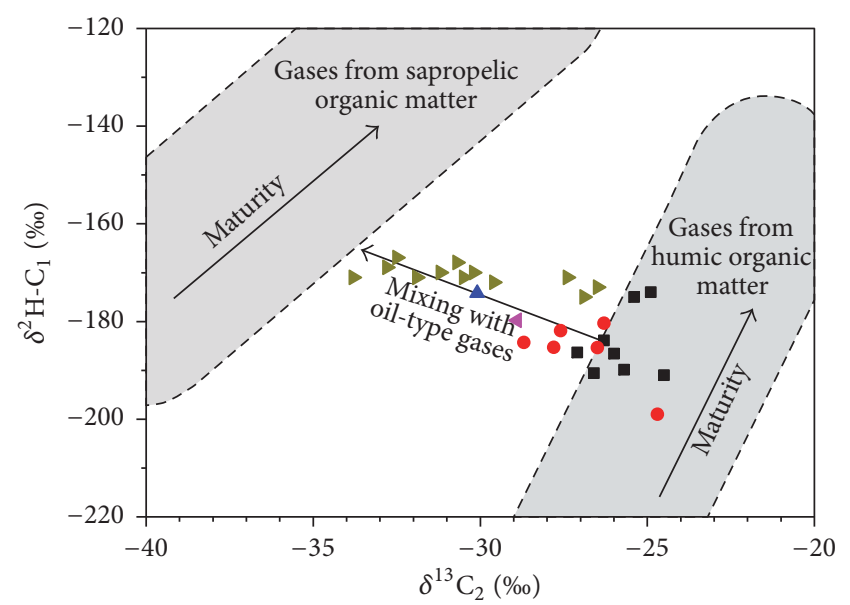

- $\mathrm{P}_{1} \mathrm{x}$, Shiguhao - $\mathrm{P}_{1} \mathrm{x}+\mathrm{P}_{1} \mathrm{~s}$, Shilijiahan $\quad \mathrm{O}_{1} \mathrm{~m}$, Jingbian $\triangleleft \mathrm{P}_{1} \mathrm{x}$, Gongkahan

(b)

Figure 9: Correlation diagrams of $\delta^{2} \mathrm{H}-\mathrm{C}_{1}$ versus $\delta^{13} \mathrm{C}_{1}$ (a) and $\delta^{2} \mathrm{H}-\mathrm{C}_{1}$ versus $\delta^{13} \mathrm{C}_{2}$ (b) of tight gas from the Hangjinqi area (modified after Wang et al. [13]). Data of the $\mathrm{O}_{1} \mathrm{~m}$ gas in the Jingbian gas fields are from Dai [18].

5.2. Source of Tight Gas. The Upper Paleozoic coal-type gas in the Ordos Basin has been commonly accepted to be derived from the $\mathrm{C}_{3} \mathrm{t}-\mathrm{P}_{1}$ s coal-measure source rocks [19-26]. Only a set of humic source rocks, that is, the $\mathrm{C}_{3} \mathrm{t}-\mathrm{P}_{1} \mathrm{~s}$ coal measures, is developed in the Hangjinqi area in northern Ordos Basin. It is believed to be the source of the Upper Paleozoic coaltype gas in this area. However, it is controversial whether the gas was generated from in situ source rocks in the Hangjinqi area $[34,35]$ or had been contributed by source rocks in the Wushenqi area in central Ordos Basin [37]. Since the $\mathrm{C}_{3} \mathrm{t}$ coalmeasure source rocks are undeveloped to the north of the Borjianghaizi fault [47], there is no consensus on whether the $\mathrm{C}_{3} \mathrm{t}-\mathrm{P}_{1} \mathrm{~s}$ coal measures to the south of the fault have contributed to the $\mathrm{P}_{1} \mathrm{~s}-\mathrm{P}_{1} \mathrm{x}$ tight gas in the Shiguhao zone to the north of the Borjianghaizi fault $[31,34-36]$.

The $\mathrm{C}_{3} \mathrm{t}-\mathrm{P}_{1} \mathrm{~s}$ coal-measure source rocks in the Hangjinqi area are gas-prone with kerogen type III; however, the development of the $\mathrm{C}_{3} \mathrm{t}-\mathrm{P}_{1}$ s source rocks to the south and north of the Borjianghaizi fault is significantly different. Only the $\mathrm{P}_{1} \mathrm{~s}$ coal-measure source rocks are generally developed in the Shiguhao zone to the north of the Borjianghaizi fault with the thickness and $R_{\mathrm{o}}$ value generally lower than $30 \mathrm{~m}$ and $1.1 \%$ (Figure 1), respectively, and the cumulative gas generation intensity is in the range of $0-10 \times 10^{8} \mathrm{~m}^{3} / \mathrm{km}^{2}[31,35]$. However, both the $\mathrm{C}_{3} \mathrm{t}$ and $\mathrm{P}_{1}$ s source rocks are developed in the Shilijiahan zone to the south of the Borjianghaizi fault with the thickness and $R_{\mathrm{o}}$ value generally higher than $30 \mathrm{~m}$ and $1.1 \%$ (Figure 1), respectively. The cumulative gas generation intensity is mainly in the range of $(15-30) \times$ $10^{8} \mathrm{~m}^{3} / \mathrm{km}^{2}$ [31,35]. The exploration in recent years indicates that the gas production and reserves in the Shiguhao zone to the north of the Borjianghaizi fault with relatively poor source condition are commonly higher than those in the Shilijiahan zone to the south of the fault with favorable source condition, respectively [31].

Thermal maturity of the source rocks could be indicated by $\delta^{13} \mathrm{C}_{1}$ value of the natural gas, and the comparison between the measured $R_{\mathrm{o}}$ values of source rocks and the calculated $R_{\mathrm{o}}$ values based on $\delta^{13} \mathrm{C}_{1}$ values provides an important approach for gas-source correlation. The $\delta^{13} \mathrm{C}_{1}-R_{\mathrm{o}}$ empirical equation for coal-type gas proposed by Stahl [49] was based on the coal gas from the NW Germany, and it was suitable for the instantaneous gas generation in high-mature stage $[55,56]$. The $\delta^{13} \mathrm{C}_{1}-R_{\mathrm{o}}$ empirical equation for coal-type gas proposed by Dai and Qi [48] was based on the statistics of coal-type gases from main Chinese petroliferous basins and has been widely and effectively applied in China, and it was appropriate for the continuous and cumulative gas generation $[55,56]$.

The burial history in the Hangjinqi area indicated that the $\mathrm{P}_{1}$ s coal-measure source rocks in the Shiguhao zone had just entered the threshold of the hydrocarbon generation and had been uplifted in the Late Jurassic, and they had been continuously buried and gradually entered the mature stage in the Early Cretaceous (Figure 10(a)). The $\mathrm{C}_{3} \mathrm{t}-\mathrm{P}_{1} \mathrm{~s}$ coal-measure source rocks in the Shilijiahan zone had been continuously buried from the deposition to the end of the Early Cretaceous and continuously generated hydrocarbons from the Early Jurassic to the Early Cretaceous (Figure 10(b)). Both the Shiguhao and Shilijiahan zones have been uplifted since the Late Cretaceous with the stagnation of the hydrocarbon generation of the source rocks (Figure 10). Therefore, the hydrocarbon generation history of the $\mathrm{C}_{3} \mathrm{t}-\mathrm{P}_{1} \mathrm{~s}$ coalmeasure source rocks in the Hangjinqi area is similar to the cumulative model proposed by Dai and Qi [48] rather than the instantaneous model in high-mature stage proposed by 


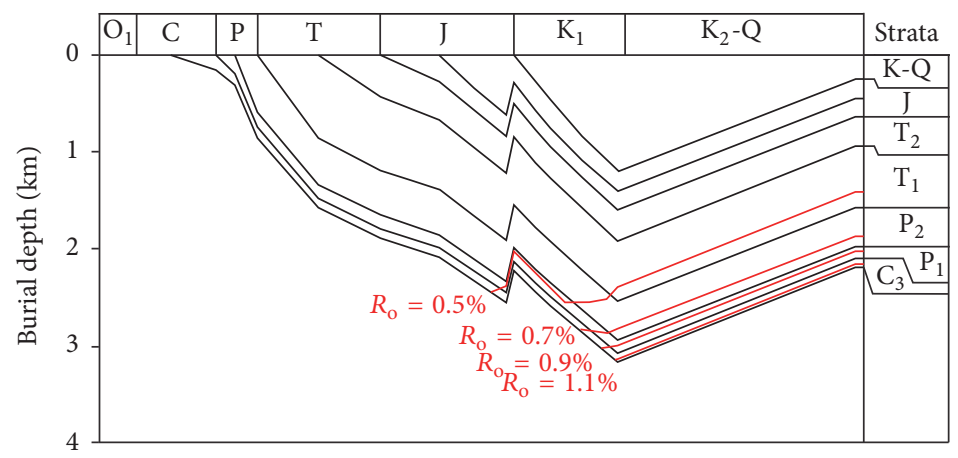

(a)

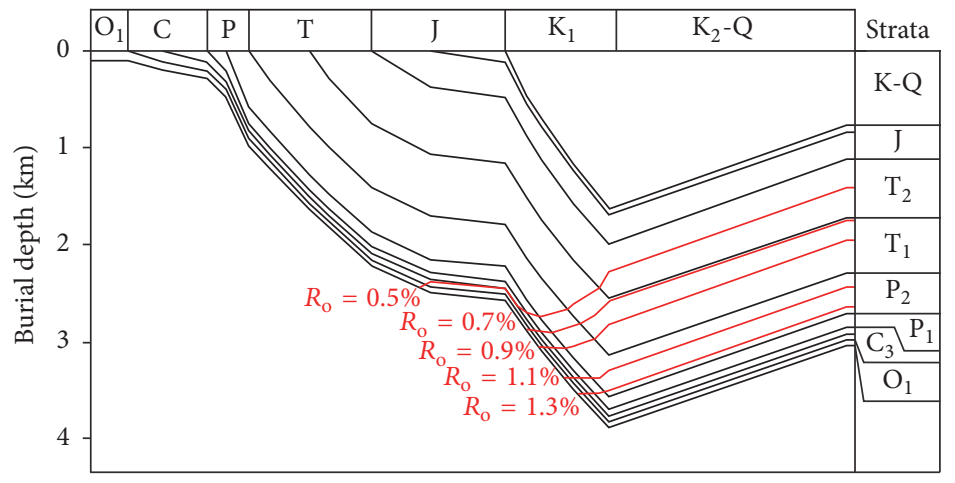

(b)

FIGURE 10: Burial and thermal evolution histories of the major stratigraphic intervals at the locations of Well JP1 in the Shiguhao gas zone (a) and Well J10 in the Shilijiahan gas zone (b) in the Hangjinqi area (modified after Hao et al. [31]).

Stahl [49]. The calculation results indicate that the calculated $R_{\mathrm{o}}$ value according to Stahl's equation is generally lower than $0.5 \%$ (Table 1 ), which is significantly different from the main measured $R_{\mathrm{o}}$ value of $0.8 \%-1.7 \%$ of the source rocks; therefore, Stahl's equation is unsuitable for tight gas in the Hangjinqi area.

The calculated $R_{\mathrm{o}}$ values of natural gas from the Shilijiahan and Gongkahan zones based on the $\delta^{13} \mathrm{C}_{1}-R_{\mathrm{o}}$ empirical equation for coal-type gas proposed by Dai and Qi [48] are in the ranges of $0.74 \%-1.38 \%$ and $0.98 \%-1.38 \%$ with the average values of $1.19 \%$ and $1.18 \%$, respectively (Table 1 ). These calculated $R_{\mathrm{o}}$ values are mainly higher than $1.1 \%$ and consistent with the measured $R_{\mathrm{o}}$ values of the $\mathrm{C}_{3} \mathrm{t}-\mathrm{P}_{1}$ s source rocks to the south of the Borjianghaizi fault (Figure 1), which indicates that the coal-type gas from the Shilijiahan and Gongkahan zones is mainly derived from in situ $\mathrm{C}_{3} \mathrm{t}-\mathrm{P}_{1} \mathrm{~s}$ source rocks. The calculated $R_{\mathrm{o}}$ value of natural gas from the Shiguhao zone based on the $\delta^{13} \mathrm{C}_{1}-R_{\mathrm{o}}$ empirical equation for coal-type gas proposed by Dai and Qi [48] is in the range of $1.28 \%-1.48 \%$ with an average of $1.37 \%$, which is significantly higher than the measured $R_{\mathrm{o}}$ value $(<1.1 \%)$ of in situ $\mathrm{P}_{1}$ s source rocks (Figure 1 ). This indicates that the Upper Paleozoic tight gas in the Shiguhao zone was mainly derived from the coal-measure source rocks with high maturity to the south of the Borjianghaizi fault rather than in situ $\mathrm{P}_{1}$ s source rocks.

Although the source rocks in the Wushenqi area had been considered to contribute to the natural gas in the Hangjinqi area [37], the measured $R_{\mathrm{o}}$ value of the $\mathrm{C}_{3} \mathrm{t}-\mathrm{P}_{1}$ s source rocks in the Wushenqi area is generally in the range of $1.6 \%-1.8 \%$ [19]. It is obviously higher than both the measured $R_{\mathrm{o}}$ value of the source rocks (Figure 1 ) and the calculated $R_{\mathrm{o}}$ value of natural gas in the Hangjinqi area. Since the strata in the Ordos Basin are generally flat with a low dip angle, and the Upper Paleozoic reservoirs are mainly tight sandstone with low porosity and permeability, the conditions for largescale lateral migration were undeveloped $[25,34]$. Therefore, natural gas generated by the coal-measure source rocks in the Wushenqi area seems unlikely to migrate laterally to the Wushenqi area by a long distance of nearly one hundred kilometers. Moreover, the Upper Paleozoic tight gas in the Hangjinqi area is generally wet with the average $\mathrm{C}_{1} / \mathrm{C}_{1-5}$ ratio and $\delta{ }^{13} \mathrm{C}_{1}$ value of 0.910 and $-32.9 \%$, respectively (Table 1 , Figure 3(b)). However, the Upper Paleozoic tight gas in the Wushenqi area is mainly dry with the average $\mathrm{C}_{1} / \mathrm{C}_{1-5}$ ratio and $\delta^{13} \mathrm{C}_{1}$ value of 0.952 and $-32.7 \%$, respectively [18], which are both slightly higher, indicating the maturity difference rather than the migration fractionation [38]. Therefore, there is little contribution from the source rocks in the Wushenqi area in central Ordos Basin to the Upper Paleozoic tight gas in the Hangjinqi area in northern Ordos Basin.

The calculated $R_{\mathrm{o}}$ value of coal-type gas from the Shiguhao zone based on the $\delta^{13} \mathrm{C}_{1}-R_{\mathrm{o}}$ empirical equation for coal-type gas proposed by Dai and Qi [48] is in the range of $1.28 \%-1.48 \%$. It is consistent with the thermal maturity of the $\mathrm{C}_{3} \mathrm{t}-\mathrm{P}_{1} \mathrm{~s}$ coal measures (Figure 1 ) in the northern margin of 
the Yishan Slope to the south of the Borjianghaizi such as the Shilijiahan zone. Therefore, the coal-type gas in the Shiguhao zone was mainly derived from the $\mathrm{C}_{3} \mathrm{t}-\mathrm{P}_{1} \mathrm{~s}$ coal measures to the south of the Borjianghaizi zone such as the Shilijiahan zone, with probably a small amount of contribution by in situ $\mathrm{P}_{1}$ s coal measures in the Shiguhao zone.

Although several tight gas samples (J58, J58P13H, J98, J99, and J111) from the Shilijiahan zone are mainly coal-type gas, they display significant mixing by oil-type gas as indicated by low $\delta^{13} \mathrm{C}_{2}$ value $(-28.7 \%$ o $-26.3 \%$ ) (Figures $8(\mathrm{a})$ and 9(b)). The $\mathrm{P}_{1} \mathrm{x}$ (J110) and $\mathrm{Pt}_{2}$ (J101) tight gas samples from the Gongkahan zone also display similar characteristics with $\delta^{13} \mathrm{C}_{2}$ values of $-28.9 \%$ and $-30.1 \%$, respectively. These gas samples were all collected from the wells located adjacent to the Wulanjilinmiao and Borjianghaizi faults. Those tight gas samples collected from the wells (J55, J77) in the Shilijiahan zone away from the faults are typically coal-type gas with relatively higher $\delta^{13} \mathrm{C}_{2}$ values $(-24.8 \%$, $-24.7 \%$ ), and they have not been mixed by the oil-type gas (Figures $8(\mathrm{a})$ and 9(b)).

The Paleozoic oil-type gas is mainly distributed in the $\mathrm{O}_{1} \mathrm{~m}$ carbonate reservoirs, and it is believed to be derived from the $\mathrm{O}_{1} \mathrm{~m}$ carbonate rocks $[27,29,57]$ or $\mathrm{C}_{3} \mathrm{t}$ limestone $[19,20,58]$. The $\mathrm{C}_{3} \mathrm{t}$ limestone is mainly distributed in central Ordos Basin such as the Jingbian area and has been considered to contribute to the Lower Paleozoic gas in the Jingbian gas field; however, the $\mathrm{C}_{3} \mathrm{t}$ limestone is undeveloped in northern Ordos Basin such as the Hangjinqi area [19]. Although the $\mathrm{O}_{1} \mathrm{~m}$ carbonate rocks in the Ordos Basin mainly have not reached the standard of hydrocarbon generation due to the low TOC content [20], they display certain hydrocarbon generation potential; for example, the self-generated and self-reservoired oil-type gas has been discovered in the presalt $\mathrm{O}_{1} \mathrm{~m}$ reservoirs in central-eastern Ordos Basin. The presalt $\mathrm{O}_{1} \mathrm{~m}$ source rocks display an average TOC content of $0.3 \%$ with kerogen type $\mathrm{I}$, and the $\mathrm{O}_{1} \mathrm{~m}$ source rocks could generate a certain amount of oil-type gas since the samples with TOC content higher than $0.4 \%$ account for $28.2 \%$ of the total [59]. Therefore, the oil-type gas component in tight gas from the Gongkahan and Shilijiahan zones in the Hangjinqi area is inferred to be derived from the $\mathrm{O}_{1} \mathrm{~m}$ carbonate rocks, and it migrated upwards along the Wulanjilinmiao and Borjianghaizi faults.

Moreover, the $\mathrm{Pt}_{2}$ gas sample (J101) from the Hangjinqi area also displays the mixing characteristics of coal-type gas and oil-type gas, and relatively low $\delta^{13} \mathrm{C}_{2}$ and $\delta^{13} \mathrm{C}_{3}$ values indicate that the proportion of oil-type gas is slightly higher than that in the Upper Paleozoic tight gas. This may explain the reason why the calculated $R_{\mathrm{o}}$ value $(0.98 \%)$ of the $\mathrm{Pt}_{2}$ gas sample according to the $\delta^{13} \mathrm{C}_{1}-R_{\mathrm{o}}$ empirical equation for coal-type gas proposed by Dai and Qi [48] is significantly lower than that of the $\mathrm{P}_{1} \mathrm{~s}-\mathrm{P}_{1} \mathrm{x}$ tight gas. The Proterozoic mudstone in the Hangjinqi area has certain hydrocarbon generation potential with mainly kerogen type III, and the distribution range and thickness are both limited [30]. Since only a small amount of the $\mathrm{Pt}_{2}$ gas has been discovered in Wells J3, J13 and J101, it is inferred that the $\mathrm{Pt}_{2}$ gas was mainly derived from the mixing of coal-type gas from the $\mathrm{Pt}_{2}$ mudstone and oil-type gas from the $\mathrm{O}_{1} \mathrm{~m}$ carbonate rocks. The $\mathrm{Pt}_{2}$ mudstone or $\mathrm{O}_{1} \mathrm{~m}$ carbonate core samples have not been obtained in the Hangjinqi area till now. Therefore, further study needs to be conducted on the geochemical characteristics and hydrocarbon potential of the $\mathrm{Pt}_{2}$ mudstone and $\mathrm{O}_{1} \mathrm{~m}$ carbonate source rocks.

5.3. Filling Patterns of Tight Gas. The accumulation and distribution of the Upper Paleozoic tight gas in the Hangjinqi area were controlled by the Borjianghaizi fault. It experienced three obvious peaks of activity in the evolution history, that is, the Caledonian to the Early Hercynian fracture period, the Indosinian to the Early Yanshanian squeezing thrust activity period, and the Middle-Late Yanshanian strike-slip tearing activity period [43]. The studies on the homogenization temperature of the fluid inclusions and the accumulation history indicated that two periods of gas filling occurred to the Upper Paleozoic strata in the Hangjinqi area in the MiddleLate Jurassic and the Early Cretaceous, respectively [43, 46]. The $\mathrm{C}_{3} \mathrm{t}-\mathrm{P}_{1} \mathrm{~s}$ coal-measure source rocks in the Shilijiahan and Shiguhao zones entered the peak stage $\left(R_{\mathrm{o}}>0.8 \%\right)$ of hydrocarbon generation in the early and middle periods of the Early Cretaceous, respectively; that is, both the $\mathrm{C}_{3} \mathrm{t}-\mathrm{P}_{1} \mathrm{~s}$ source rocks in these two zones started to generate a large amount of natural gas in the Early Cretaceous (Figure 10). Therefore, the strike-slip activity of the Borjianghaizi fault in the Middle-Late Yanshanian effectively matched with the main gas filling period in the Early Cretaceous, and the intensive fault activity in the gas filling period was favorable for the effective expulsion of hydrocarbons from the source rocks and migration and accumulation of natural gas [43].

The study on the fault sealing ability indicated that the fault plane of the Borjianghaizi fault was vertically sealed in the $\mathrm{P}_{2}$ sh and $\mathrm{P}_{2} \mathrm{~s}$ strata with the fault sealing coefficients almost less than 1.0, whereas the fault plane was vertically open in the $\mathrm{P}_{1} \mathrm{~s}$ and $\mathrm{P}_{1} \mathrm{x}$ strata with the fault sealing coefficients mostly ranging from 4.0 to 10.0 [43]. Moreover, the $\mathrm{P}_{2}$ sh and $\mathrm{P}_{2} \mathrm{~s}$ mudstones constituted the favorable regional caprock since they display a large thickness and stable lateral distribution. Therefore, the large amount of natural gas generated by the $\mathrm{C}_{3} \mathrm{t}-\mathrm{P}_{1} \mathrm{~s}$ coal-measure source rocks to the south of the Borjianghaizi fault firstly migrated vertically along the fault and then migrated laterally across the fault to the north along the $\mathrm{P}_{1} \mathrm{x}$ stripped sand bodies (Figure 11). It finally accumulated in the favorable traps during the migration (Figure 11); that is, natural gas in the Shiguhao zone to the north of the Borjianghaizi fault mainly displayed distalsource accumulation.

Molecular fractionation of natural gas occurs during the migration process. Since the diffusion coefficient of the hydrocarbon decreases with the increase of the molecular weight [60], the diffusive gas is enriched in $\mathrm{CH}_{4}$ and displays higher $\mathrm{C}_{1} / \mathrm{C}_{1-5}$ ratio. As indicated from the section $\mathrm{A}-\mathrm{A}^{\prime}$ (Figure 11), the $\mathrm{P}_{1} \mathrm{~s}$ gas sample from Well $\mathrm{J} 55$ to the south of the Borjianghaizi fault displays $\mathrm{C}_{1} / \mathrm{C}_{1-5}$ ratio of 0.896 , whereas the $\mathrm{P}_{1} \mathrm{x}$ gas samples from Wells J66P5H, YS1, J11, and $\mathrm{J} 26$ to the north of the fault display $\mathrm{C}_{1} / \mathrm{C}_{1-5}$ ratios higher than 0.900 (Figure 11). This suggests that the $\mathrm{P}_{1} \mathrm{x}$ gas in the 


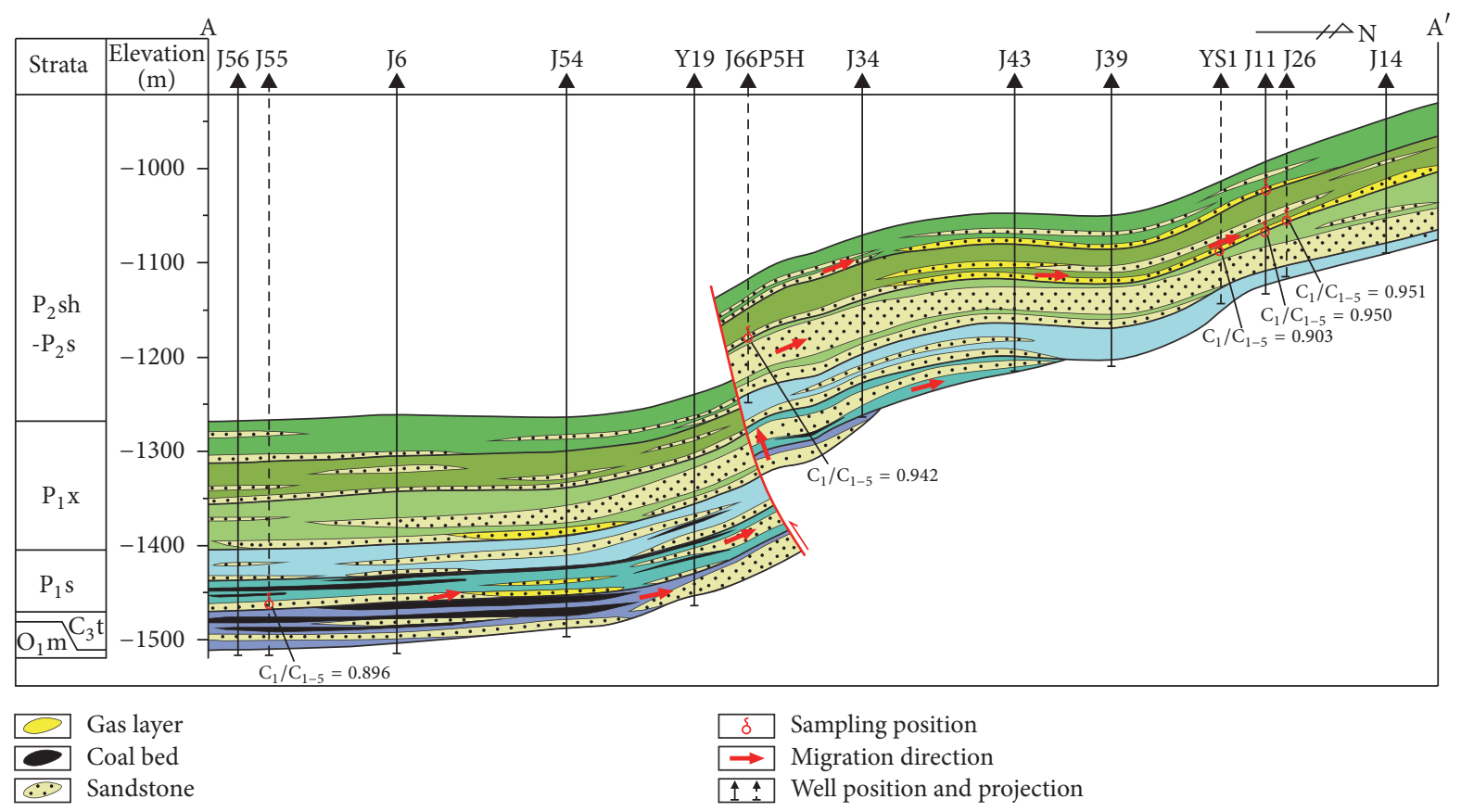

FIGURE 11: Gas filling model of the Upper Paleozoic tight gas in the Hangjinqi area, and the position of the section A-A' is indicated in Figure 1 (modified after Li et al. [43]).

reservoirs to the north of the fault has been migrated from the $\mathrm{C}_{3} \mathrm{t}-\mathrm{P}_{1}$ s coal-measure source rocks to the south of the fault.

As to the Shilijiahan zone to the south of the Borjianghaizi fault, since the strata dipped to the south due to the effect of the thrusting in the Late Jurassic, natural gas which had migrated upwards along the fault seemed unfavorable to fill into in situ $\mathrm{P}_{1} \mathrm{~s}$ and $\mathrm{P}_{1} \mathrm{x}$ sand bodies (Figure 11). Therefore, natural gas in the Shilijiahan zone was mainly derived from in situ $\mathrm{C}_{3} \mathrm{t}$ and $\mathrm{P}_{1} \mathrm{~s}$ source rocks. The migration pathways were mainly the sand bodies and fissures with the driving force of the pressure difference between source rocks and the reservoirs, which affected the degree of gas accumulation. Consequently, tight gas in the Shilijiahan and Gongkahan zones mainly displayed near-source accumulation. Moreover, the gas samples which had been mixed by the oil-type gas were all collected from the wells adjacent to the Borjianghaizi and Wulanjilinmiao faults, and the oil-type gas component was inferred to be derived from the $\mathrm{O}_{1} \mathrm{~m}$ carbonate rocks and migrate upwards along the two faults.

\section{Conclusions}

(1) The Upper Paleozoic tight gas in the Hangjinqi area in northern Ordos Basin is mainly wet gas with the dryness coefficient $\left(\mathrm{C}_{1} / \mathrm{C}_{1-5}\right)$ of $0.853-0.951$, which is positively correlated with the $\mathrm{CH}_{4}$ content. The $\delta^{13} \mathrm{C}_{1}, \delta^{13} \mathrm{C}_{2}$, and $\delta^{13} \mathrm{C}_{3}$ values are ranging from $-36.2 \%$ o to $-32.0 \%$, from $-28.9 \%$ o to $-24.5 \%$, and from $-26.6 \%$ to $-19.5 \%$, respectively, with the $\delta^{2} \mathrm{H}$ $\mathrm{C}_{1}$ values from $-199 \%$ o to $-174 \%$. The alkane gas generally displays positive carbon and hydrogen isotopic series, with only a few gas samples being partially reversed between $\mathrm{C}_{2} \mathrm{H}_{6}$ and $\mathrm{C}_{3} \mathrm{H}_{8}$.
(2) Integrated analysis on geochemical characteristics from the alkane carbon and hydrogen isotopes demonstrates that the Upper Paleozoic tight gas in the Hangjinqi area is mainly coal-type gas. The carbon isotopic compositions of ethane and propane indicate that tight gas from the wells in the Shilijiahan and Gongkahan zones adjacent to the Wulanjilinmiao and Borjianghaizi faults has been affected by the mixing of oil-type gas, and it displays similar geochemical characteristics with the $\mathrm{O}_{1} \mathrm{~m}$ gas in the Jingbian gas field. However, the proportion of oil-type gas in the Upper Paleozoic gas in the Shilijiahan and Gongkahan zones is slightly lower than that in the $\mathrm{O}_{1} \mathrm{~m}$ gas in the Jingbian gas field.

(3) Gas-source correlation indicated that the coal-type gas in the Shiguhao zone displayed distal-source accumulation, and it was mainly derived from the $\mathrm{C}_{3} \mathrm{t}-\mathrm{P}_{1} \mathrm{~s}$ coal-measure source rocks, probably with a minor contribution from the $\mathrm{P}_{1}$ s coal measures in in situ Shiguhao zone. Tight gas in the Shilijiahan and Gongkahan zones mainly displayed near-source accumulation. The coal-type gas component was derived from in situ $\mathrm{C}_{3} \mathrm{t}-\mathrm{P}_{1} \mathrm{~s}$ source rocks, whereas the oiltype gas component might be derived from the $\mathrm{O}_{1} \mathrm{~m}$ carbonate rocks, and it migrated upwards along the Wulanjilinmiao and Borjianghaizi faults.

\section{Conflicts of Interest}

The authors declare that there are no conflicts of interest regarding the publication of this paper.

\section{Acknowledgments}

The authors would like to thank Professor Jinxing Dai and Deliang Liu for generous guidance and assistance, the North 
China Branch Company of SINOPEC for sample collection and technical support, and Key Laboratory for Hydrocarbon Accumulation Mechanism of SINOPEC for chemical analyses of natural gas. This work was supported by the National Natural Science Foundation of China (Grants nos. 41625009, U1663201, and 41302118) and the National Science \& Technology Special Project (Grant no. 2016ZX05002-006).

\section{References}

[1] M. Schoell, "The hydrogen and carbon isotopic composition of methane from natural gases of various origins," Geochimica et Cosmochimica Acta, vol. 44, no. 5, pp. 649-661, 1980.

[2] A. A. Prinzhofer and A. Y. Huc, "Genetic and post-genetic molecular and isotopic fractionations in natural gases," Chemical Geology, vol. 126, no. 3-4, pp. 281-290, 1995.

[3] M. A. Rooney, G. E. Claypool, and H. Moses Chung, "Modeling thermogenic gas generation using carbon isotope ratios of natural gas hydrocarbons," Chemical Geology, vol. 126, no. 3-4, pp. 219-232, 1995.

[4] M. J. Whiticar, "Carbon and hydrogen isotope systematics of bacterial formation and oxidation of methane," Chemical Geology, vol. 161, no. 1, pp. 291-314, 1999.

[5] Y. Tang, J. K. Perry, P. D. Jenden, and M. Schoell, "Mathematical modeling of stable carbon isotope ratios in natural gases," Geochimica et Cosmochimica Acta, vol. 64, no. 15, pp. 2673-2687, 2000.

[6] Y. Ni, Q. Ma, G. S. Ellis et al., "Fundamental studies on kinetic isotope effect (KIE) of hydrogen isotope fractionation in natural gas systems," Geochimica et Cosmochimica Acta, vol. 75, no. 10, pp. 2696-2707, 2011.

[7] Q. Y. Liu, R. H. Worden, Z. J. Jin et al., “TSR versus non-TSR processes and their impact on gas geochemistry and carbon stable isotopes in carboniferous, permian and lower triassic marine carbonate gas reservoirs in the Eastern Sichuan Basin, China," Geochimica et Cosmochimica Acta, vol. 100, no. 1, pp. 96-115, 2013.

[8] Q. Y. Liu, R. H. Worden, Z. J. Jin et al., "Thermochemical sulphate reduction (TSR) versus maturation and their effects on hydrogen stable isotopes of very dry alkane gases," Geochimica et Cosmochimica Acta, vol. 137, no. 0, pp. 208-220, 2014.

[9] Q. Liu, J. Dai, Z. Jin et al., "Abnormal carbon and hydrogen isotopes of alkane gases from the Qingshen gas field, Songliao Basin, China, suggesting abiogenic alkanes?” Journal of Asian Earth Sciences, vol. 115, no. 1, pp. 285-297, 2016.

[10] Q. Liu, Z. Jin, J. Li, A. Hu, and C. Bi, "Origin of marine sour natural gas and gas-filling model for the wolonghe gas field, Sichuan Basin, China," Journal of Asian Earth Sciences, vol. 58, pp. 24-37, 2012.

[11] F. Hao, X. Zhang, C. Wang et al., "The fate of $\mathrm{CO}_{2}$ derived from thermochemical sulfate reduction (TSR) and effect of TSR on carbonate porosity and permeability, Sichuan Basin, China," Earth-Science Reviews, vol. 141, pp. 154-177, 2015.

[12] Y. Ni, J. Dai, C. Zou, F. Liao, Y. Shuai, and Y. Zhang, "Geochemical characteristics of biogenic gases in China," International Journal of Coal Geology, vol. 113, pp. 76-87, 2013.

[13] X. Wang, W. Liu, B. Shi, Z. Zhang, Y. Xu, and J. Zheng, "Hydrogen isotope characteristics of thermogenic methane in chinese sedimentary basins," Organic Geochemistry, vol. 83-84, no. 1, pp. 178-189, 2015.
[14] F. Hao and H. Zou, "Cause of shale gas geochemical anomalies and mechanisms for gas enrichment and depletion in highmaturity shales," Marine and Petroleum Geology, vol. 44, pp. 112, 2013.

[15] J. Dai, C. Zou, D. Dong et al., "Geochemical characteristics of marine and terrestrial shale gas in China," Marine and Petroleum Geology, vol. 76, pp. 444-463, 2016.

[16] J. Dai, Y. Ni, and X. Wu, "Tight gas in China and its significance in exploration and exploitation," Petroleum Exploration and Development, vol. 39, no. 3, pp. 277-284, 2012.

[17] J. Dai, C. Yu, S. Huang et al., "Geological and geochemical characteristics of large gas fields in China," Petroleum Exploration and Development, vol. 41, no. 1, pp. 1-13, 2014.

[18] J. Dai, Giant Coal-Derived Gas Fields and the Source in China, Science Press, Beijing, China, 2014.

[19] J. Dai, J. Li, X. Luo et al., "Stable carbon isotope compositions and source rock geochemistry of the giant gas accumulations in the Ordos Basin, China," Organic Geochemistry, vol. 36, no. 12, pp. 1617-1635, 2005.

[20] A. Hu, J. Li, W. Zhang, Z. Li, L. Hou, and Q. Liu, “Geochemical characteristics and origin of gases from the Upper, Lower Paleozoic and the Mesozoic reservoirs in the Ordos Basin, China," Science in China, Series D: Earth Sciences, vol. 51, supplement I, pp. 183-194, 2008.

[21] H. Yang, J. Fu, X. Liu, and P. Meng, "Accumulation conditions and exploration and development of tight gas in the Upper Paleozoic of the Ordos Basin," Petroleum Exploration and Development, vol. 39, no. 3, pp. 295-303, 2012.

[22] G. Hu, J. Li, X. Shan, and Z. Han, "The origin of natural gas and the hydrocarbon charging history of the Yulin gas field in the Ordos Basin, China," International Journal of Coal Geology, vol. 81, no. 4, pp. 381-391, 2010.

[23] S. Huang, X. Fang, D. Liu, C. Fang, and T. Huang, "Natural gas genesis and sources in the Zizhou gas field, Ordos Basin, China," International Journal of Coal Geology, vol. 152, part A, pp. 132143,2015

[24] H. Yang, J. Fu, X. Wei, and X. Liu, "Sulige field in the Ordos Basin: geological setting, field discovery and tight gas reservoirs," Marine and Petroleum Geology, vol. 25, no. 4-5, pp. 387-400, 2008.

[25] C. N. Zou, Z. Yang, S. Z. Tao et al., "Continuous hydrocarbon accumulation over a large area as a distinguishing characteristic of unconventional petroleum: the Ordos Basin, North-Central China," Earth-Science Reviews, vol. 126, pp. 358-369, 2013.

[26] Q. Liu, Z. Jin, Q. Meng, X. Wu, and H. Jia, "Genetic types of natural gas and filling patterns in Daniudi gas field, Ordos Basin, China," Journal of Asian Earth Sciences, vol. 107, pp. 1-11, 2015.

[27] Q. Y. Liu, Z. J. Jin, Y. Wang et al., "Gas filling pattern in Paleozoic marine carbonate reservoir of Ordos Basin," Acta Petrologica Sinica, vol. 28, no. 3, pp. 847-858, 2012.

[28] C. Cai, G. Hu, H. He, J. Li, J. Li, and Y. Wu, "Geochemical characteristics and origin of natural gas and thermochemical sulphate reduction in Ordovician carbonates in the Ordos Basin, China," Journal of Petroleum Science and Engineering, vol. 48, no. 3-4, pp. 209-226, 2005.

[29] Q. Liu, M. Chen, W. Liu, J. Li, P. Han, and Y. Guo, "Origin of natural gas from the Ordovician paleo-weathering crust and gas-filling model in Jingbian gas field, Ordos Basin, China," Journal of Asian Earth Sciences, vol. 35, no. 1, pp. 74-88, 2009. 
[30] S. Peng, The Analyzation of Middle-Late Proterozoic Hydrocarbon Geologic Feature and Exploration Potential in Hangjinqi Area, Northwest University, Xian, China, 2009.

[31] S. Hao, L. Li, W. Zhang, R. Qi, C. Ma, and J. Chen, "Forming conditions of large-scale gas fields in Permo-Carboniferous in the northern Ordos Basin," Oil and Gas Geology, vol. 37, no. 2, pp. 149-154, 2016.

[32] M. Yang, L. Li, J. Zhou et al., "Mesozoic structural evolution of the Hangjinqi area in the northern Ordos Basin, North China," Marine and Petroleum Geology, vol. 66, pp. 695-710, 2015.

[33] M. Yang, L. Li, J. Zhou, X. Qu, and D. Zhou, "Segmentation and inversion of the Hangjinqi fault zone, the Northern Ordos Basin (North China)," Journal of Asian Earth Sciences, vol. 70-71, no. 1, pp. 64-78, 2013.

[34] H. Xue, J.-C. Zhang, B. Xu, Y. Wang, and X.-P. Mao, "Evaluation of Upper Paleozoic source rocks of the Hangjinqi block in the northern Ordos Basin, China," Journal of Chengdu University of Technology (Science and Technology Edition), vol. 37, no. 1, pp. 21-28, 2010.

[35] W.-M. Ji, W.-L. Li, Z. Liu, and T. Lei, "Research on the Upper Paleozoic gas source of the Hangjinqi block in the northern Ordos Basin," Natural Gas Geoscience, vol. 24, no. 5, pp. 905914, 2013.

[36] J. Chen, H. Jia, Y. Li, C. An, W. Li, and S. Liu, "Origin and source of natural gas in the Upper Paleozoic of the Yimeng Uplift, Ordos Basin," Oil and Gas Geology, vol. 37, no. 2, pp. 205-209, 2016.

[37] M. Wang, D. He, H. Bao, R. Lu, and B. Gui, "Upper Palaeozoic gas accumulations of the Yimeng Uplift, Ordos Basin," Petroleum Exploration and Development, vol. 38, no. 1, pp. 3039, 2011.

[38] A. Prinzhofer and E. Pernaton, "Isotopically light methane in natural gas: bacterial imprint or diffusive fractionation?" Chemical Geology, vol. 142, no. 3-4, pp. 193-200, 1997.

[39] A. Prinzhofer and A. Battani, "Gas isotopes tracing: An important tool for hydrocarbons exploration," Oil and Gas Science and Technology, vol. 58, no. 2, pp. 299-311, 2003.

[40] B. B. Bernard, J. M. Brooks, and W. M. Sackett, "Natural gas seepage in the Gulf of Mexico," Earth and Planetary Science Letters, vol. 31, no. 1, pp. 48-54, 1976.

[41] P. D. Jenden, I. R. Kaplan, R. Poreda, and H. Craig, "Origin of nitrogen-rich natural gases in the California Great Valley: evidence from helium, carbon and nitrogen isotope ratios," Geochimica et Cosmochimica Acta, vol. 52, no. 4, pp. 851-861, 1988.

[42] J. Dai, "Significant advancement in research on coal-derived gas in China," Petroleum Exploration and Development, vol. 26, no. 3, pp. 1-10, 1999.

[43] W. Li, W. Ji, and Z. Liu, "Control of Boerjianghaizi fault on gas accumulation of Upper Paleozoic in northern Ordos Basin," Geoscience, vol. 29, no. 3, pp. 584-590, 2015.

[44] J. Yang and X. Pei, Natural Gas Geology in China, vol. 4, Petroleum Industry Press, Beijing, China, 1996.

[45] Y. Yang, W. Li, and L. Ma, "Tectonic and stratigraphic controls of hydrocarbon systems in the Ordos Basin: a multicycle cratonic basin in central China," AAPG Bulletin, vol. 89, no. 2, pp. 255269, 2005.

[46] H. Xue, Y. Wang, and X. Mao, "The timing of gas pooling in the Upper Paleozoic in the northern Ordos Basin: A case study of the Hangjinqi Block," Natural Gas Industry, vol. 29, no. 12, pp. $9-12,2009$.
[47] B. Xu, H. Nie, and M. Wang, "A study of hydrocarbongenerating potential of Hangjinqi prospect area in ordos basin," Petroleum Geology and Recovery Efficiency, vol. 16, no. 4, pp. 3839, 2009.

[48] J. Dai and H. Qi, “The $\delta^{13}$ C-Ro relationship of coal-derived alkane gases in China," Chinese Science Bulletin, vol. 34, no. 9, pp. 690-692, 1989.

[49] W. J. Stahl, "Carbon and nitrogen isotopes in hydrocarbon research and exploration," Chemical Geology, vol. 20, no. C, pp. 121-149, 1977.

[50] J. Dai, X. Pei, and H. Qi, Natural Gas Geology in China, vol. 1, Petroleum Industry Press, Beijing, China, 1992.

[51] Q. Liu, J. Dai, J. Li, and Q. Zhou, "Hydrogen isotope composition of natural gases from the Tarim Basin and its indication of depositional environments of the source rocks," Science in China, Series D: Earth Sciences, vol. 51, no. 2, pp. 300-311, 2008.

[52] J. Dai, Y. Ni, and C. Zou, "Stable carbon and hydrogen isotopes of natural gases sourced from the Xujiahe Formation in the Sichuan Basin, China," Organic Geochemistry, vol. 43, no. 1, pp. 103-111, 2012.

[53] G. Hu and S. Zhang, "Characterization of low molecular weight hydrocarbons in Jingbian gas field and its application to gas sources identification," Energy Exploration and Exploitation, vol. 29, no. 6, pp. 777-796, 2011.

[54] Y.-R. Zou, Y. Cai, C. Zhang, X. Zhang, and P. Peng, "Variations of natural gas carbon isotope-type curves and their interpretation-a case study," Organic Geochemistry, vol. 38, no. 8, pp. 1398-1415, 2007.

[55] W. Liu and Y. Xu, "A two-stage model of carbon isotopic fractionation in coal-gas," Geochimica, vol. 28, no. 4, pp. 359365, 1999.

[56] E. M. Galimov, "Isotope organic geochemistry," Organic Geochemistry, vol. 37, no. 10, pp. 1200-1262, 2006.

[57] S. Hao, Y. Gao, and Z. Huang, "Characteristics of dynamic equilibrium for natural gas migration and accumulation of the gas field in the center of the Ordos Basin," Science in China, Series D: Earth Sciences, vol. 40, no. 1, pp. 11-15, 1997.

[58] X. Xia, L. Zhao, W. Zhang, and J. Li, "Geochemical characteristics and source rock of Ordovician gas reservoir, Changqing Gasfield," Chinese Science Bulletin, vol. 44, no. 20, pp. 1917-1920, 1999.

[59] D. Liu, W. Zhang, Q. Kong, Z. Feng, C. Fang, and W. Peng, "Lower Paleozoic source rocks and natural gas origins in Ordos Basin, NW China," Petroleum Exploration and Development, vol. 43, no. 4, pp. 591-601, 2016.

[60] B. M. Krooss and D. Leythaeuser, "Experimental measurements of the diffusion parameters of light hydrocarbons in watersaturated sedimentary rocks-II. Results and geochemical significance," Organic Geochemistry, vol. 12, no. 2, pp. 91-108, 1988. 

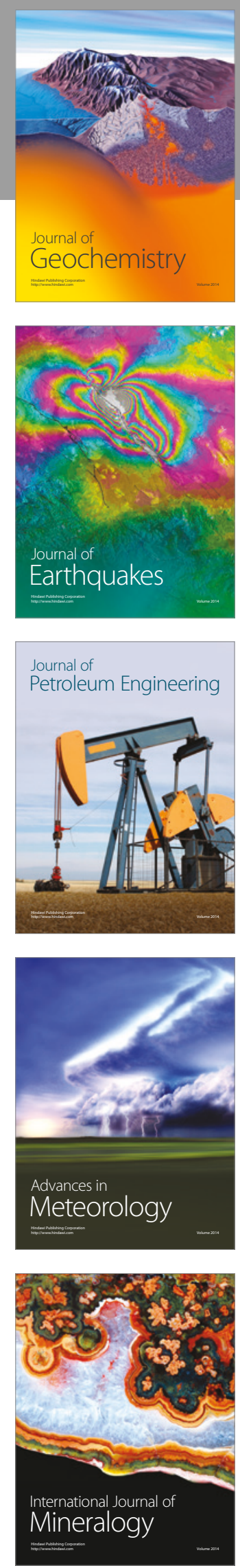
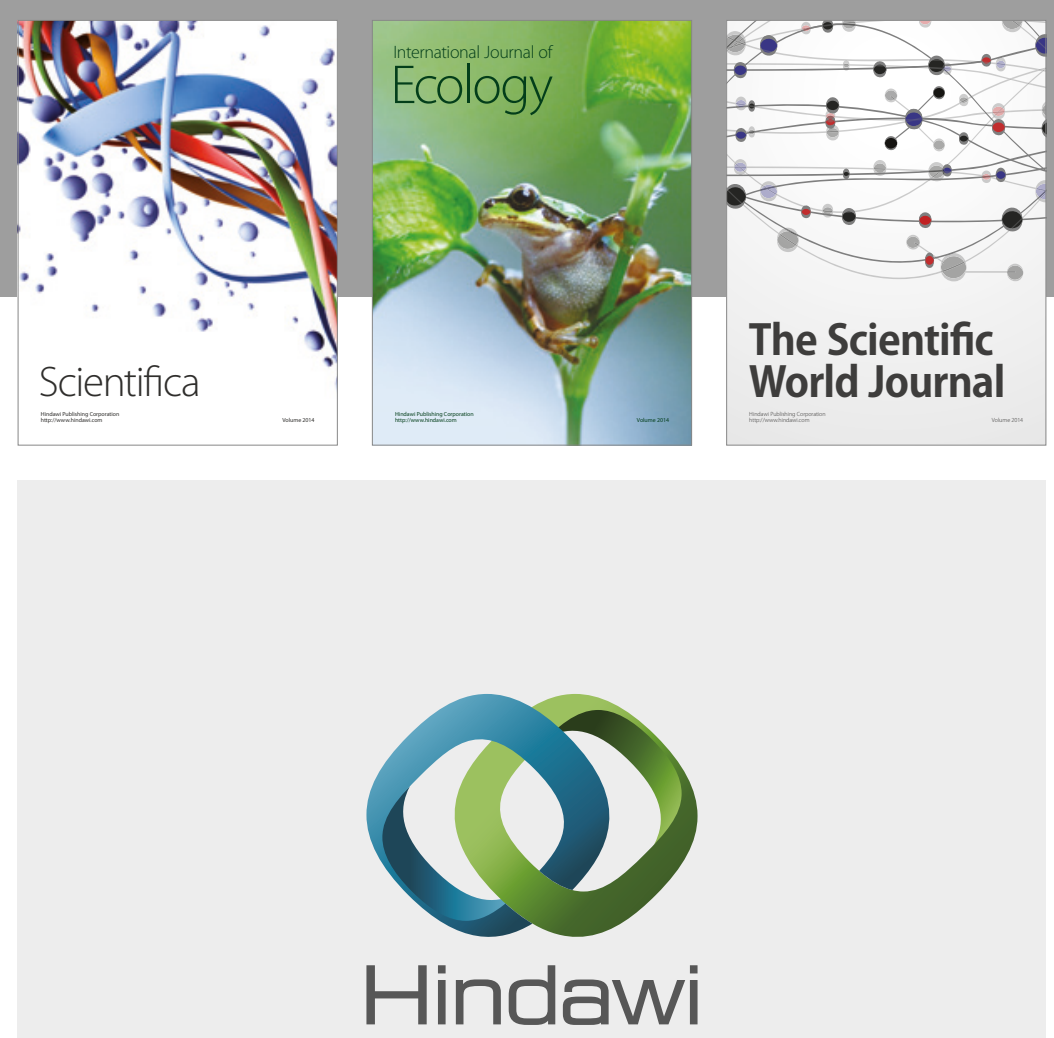

Submit your manuscripts at

https://www.hindawi.com
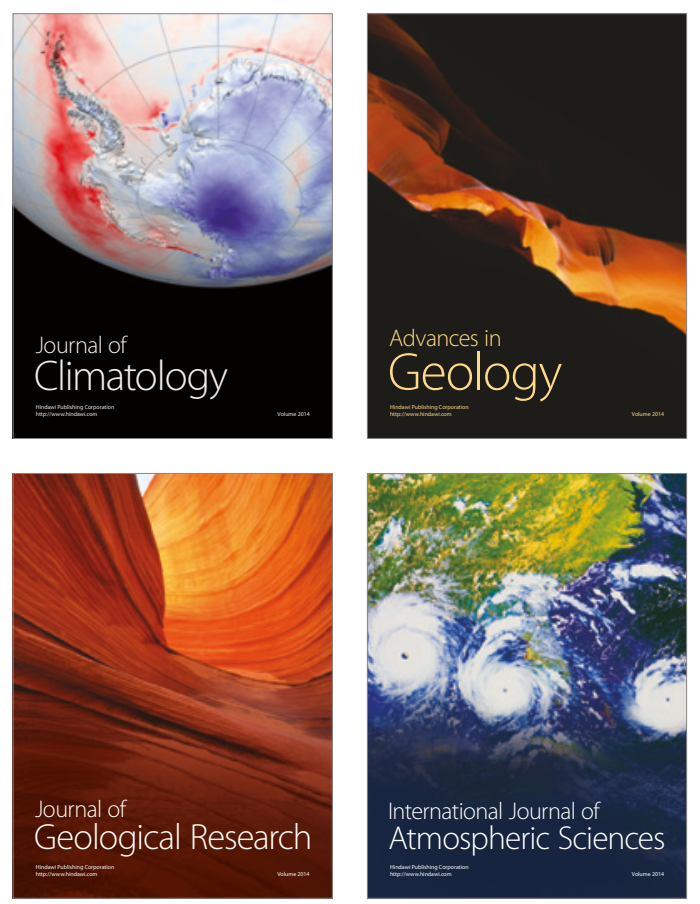

The Scientific

World Journal
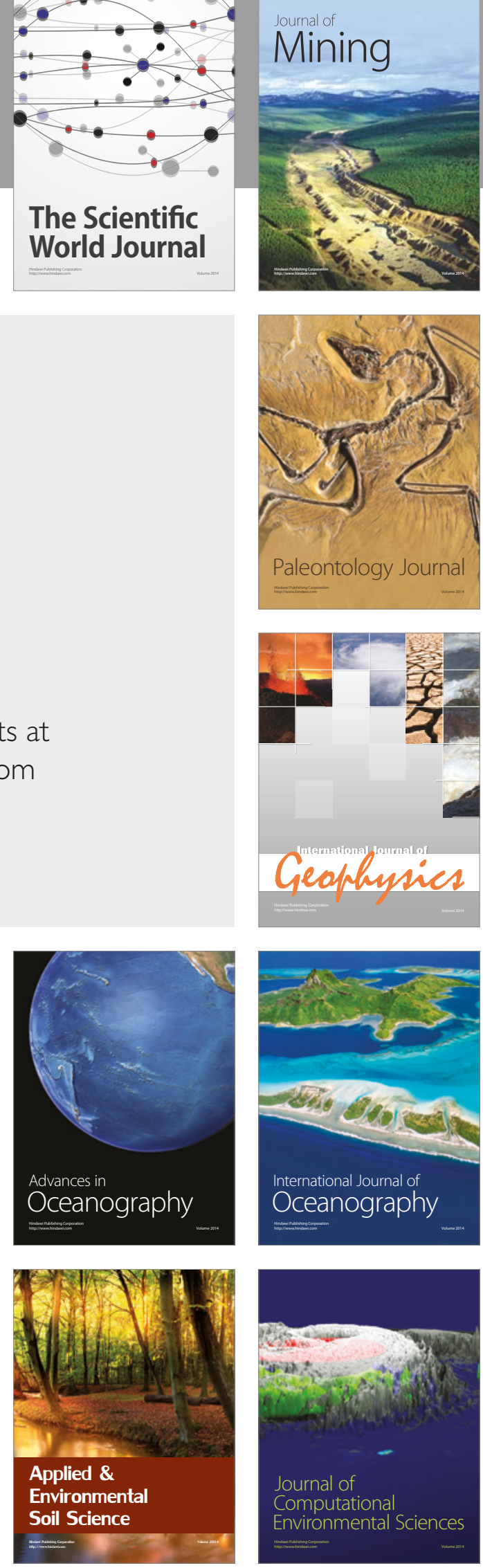